\title{
Article \\ Corrosion Activity of Carbon Steel B450C and Low Chromium Ferritic Stainless Steel 430 in Cement Extract Solution
}

\author{
Ángel Bacelis ${ }^{1} \mathbb{D}$, Lucien Veleva ${ }^{1, * \mathbb{D}}$, Sebastián Feliu, Jr. ${ }^{2} \mathbb{D}$, Marina Cabrini ${ }^{3} \mathbb{D}$ and Sergio Lorenzi ${ }^{3} \mathbb{D}$ \\ 1 Applied Physics Department, Center for Investigation and Advanced Study (CINVESTAV), \\ Merida 97310, Mexico; angel.bacelis@cinvestav.mx \\ 2 Nacional Center for Metallurgical Research (CENIM-CSIC), Surface Engineering, \\ Corrosion and Durability Department, 28040 Madrid, Spain; sfeliu@cenim.csic.es \\ 3 Department of Engineering and Applied Sciences, INSTM RU Bergamo and University of Bergamo, \\ Viale Marconi 5, 24044 Dalmine, Italy; marina.cabrini@unibg.it (M.C.); sergio.lorenzi@unibg.it (S.L.) \\ * Correspondence: veleva@cinvestav.mx; Tel.: +52-999-942-9400
}

Citation: Bacelis, Á.; Veleva, L.; Feliu,

S., Jr.; Cabrini, M.; Lorenzi, S.

Corrosion Activity of Carbon Steel B450C and Low Chromium Ferritic Stainless Steel 430 in Cement Extract Solution. Buildings 2021, 11, 220. https://doi.org/10.3390/ buildings11060220

Academic Editor: Lech Czarnecki

Received: 20 April 2021

Accepted: 18 May 2021

Published: 21 May 2021

Publisher's Note: MDPI stays neutral with regard to jurisdictional claims in published maps and institutional affiliations.

Copyright: (c) 2021 by the authors. Licensee MDPI, Basel, Switzerland. This article is an open access article distributed under the terms and conditions of the Creative Commons Attribution (CC BY) license (https:/ / creativecommons.org/licenses/by/ $4.0 /)$.

\begin{abstract}
This study compares corrosion activities of carbon steel B450C and SS 430 (Mn in low content) exposed for 30 days in cement extract solution. Iron oxide and hydroxide were formed as corrosion products, in addition to $\mathrm{CaCO}_{3}$, in the presence of $\mathrm{Cr}_{2} \mathrm{O}_{3}$ on SS 430. Because of the decrease in $\mathrm{pH}, \mathrm{B} 450 \mathrm{C}$ lost the passive state when OCP shifted to negative values, while SS 430 showed positive OCP values, maintaining its passive state. The SEM images confirmed that the corrosion attack on the surface was less aggressive for SS 430. The Nyquist plots of EIS initially showed capacitive behavior and later changed to semi-linear diffusion impedance, which SS 430 maintained firmly. The phase angle Bode diagrams confirmed these changes. Two equivalent circuits were applied. The calculated values of $R_{p}$ for SS 430 increased over time (protective passive layer mainly of $\mathrm{Cr}_{2} \mathrm{O}_{3}$ oxide), while for carbon steel, $R_{p}$ reached maximum value after $168 \mathrm{~h}$ and then decreased, maintaining minimum values approximately five orders lower than those of the stainless steel.
\end{abstract}

Keywords: carbon steel; stainless steel; concrete pore; cement extract; corrosion tests; XPS

\section{Introduction}

Concrete is one of the most widely used materials in the construction industry because of low cost and mechanical performance [1]. Concrete supports compressive stresses; however, it is susceptible to cracking due to other types of mechanical stresses such as bending, traction, torsion, and shear, among others. Steel bars to reinforce concrete provides resistance to these forces because of the steel-concrete union [2]. To confront the highly aggressive environments, stainless steels (Fe-Cr based alloys) have been proposed as reinforcement on account of their excellent mechanical properties and high resistance to corrosion, which guarantee the durability and service life of the reinforced concrete structure [3].

The stability of carbon steel reinforcement lies in the formation of passivation layers of oxides/oxyhydroxides of nanometric thickness (circa $20 \mathrm{~nm}$ ), responsible for the very low corrosion rate of the reinforcing bars in their passive state [4,5]. Usually, this layer is composed of an inner one rich in Fe (II) oxides/oxyhydroxides and an outer one containing Fe (III) oxides/oxyhydroxides [6,7]. The high corrosion resistance of stainless steels (SS) results from the formation of a continuous, protective surface oxide layer, giving rise to the passive state of the metal surface [8,9]. The native oxide formed on Fe-Cr-based stainless steel surfaces generally shows a duplex structure, with an iron-rich outer layer and a chromium-rich inner layer $[6,7,9-12]$. The chromium-rich oxide plays a key role in the corrosion resistance [13-15].

The passive steel state disappears when the passivation layer loses thickness because of the initiation of the corrosion process, which leads to a loss of steel-concrete adhesion and, 
therefore, to a loss in the mechanical properties of reinforced concrete; this is accompanied by micro- and macro-cracks as well as localized pitting penetration in the SS passive layer. Thus, the thickening of the corrosion layer may promote the detachment of the concrete cover because of the mechanical internal stresses of corrosion products of iron formed on the carbon steel surface, which are usually voluminous [16].

According to the Pourbaix diagram, the passivity of the carbon steel occurs naturally in alkaline media [17]. Portland cement, Portlandite $\left(\mathrm{Ca}(\mathrm{OH})_{2}\right)$, provides the necessary highly alkaline environment in concrete [4].

The concepts of $\mathrm{pH}$ and steel passivity require the presence of alkaline concrete pore solution, as a hydration product of cement $(\mathrm{pH}>12.5)$, when the structure is exposed to natural environments, considering that the concrete pores (from micrometer to nanometer size $[18,19])$ could maintain that same $\mathrm{pH}$ of aqueous solution.

It is well known that cathodic reaction plays an important role in the establishment of the equilibrium of a corrosion process. In alkaline and neutral electrolytes, the reaction occurs as oxygen reduction (Equation (1)) over time at the steel-concrete surface, and it is suggested that this reaction mainly occurs on oxidized porous surfaces, which are complex in composition and in morphology [20]. In this respect, the decrease in the amount of the diffused $\mathrm{O}_{2}$ and an increase in $\mathrm{OH}^{-}$ion content may inhibit the reaction.

$$
\mathrm{O}_{2}+2 \mathrm{H}_{2} \mathrm{O}+4 \mathrm{e}^{-} \leftarrow \rightarrow 4 \mathrm{OH}^{-}
$$

Furthermore, as the ferrous iron is soluble in water at any $\mathrm{pH}$ [21], the hydrolysis of free ferrous ions may cause a local diminishing of $\mathrm{pH}$ as well as oxide reduction, responsible for the passive iron state. On the other hand, the alkaline $\mathrm{pH}$ value may diminish because of $\mathrm{CO}_{2}$ ambient pollution when a phenomenon known as carbonation occurs, as a transformation of $\mathrm{Ca}(\mathrm{OH})_{2}$ into $\mathrm{CaCO}_{3}[4,18,22]$.

As an important part of the internal environment of concrete, the pore solution plays a considerable role in preventing or accelerating the steel corrosion [23]. A variety of alkaline solutions simulating the electrolytic environments of concrete pores have been used in order to evaluate the electrochemical behavior of steel-reinforced concrete over a short period of time, although the proposed models differ in the results obtained [24-26]. Furthermore, a major concern is the composition of alkaline solutions, which may influence the corrosion resistance of steels, as well as the composition of the corrosion products formed [26-32]. Few works have proposed the use of cement extract solution, which may provide variety with regards to the ions found in the concrete pores in real conditions [33-37]. There is still considerable controversy about the effect of the composition of the model solution on the electrochemical behavior of steels [38].

This research compares the corrosion activity of commercial Italian carbon steel to that of low chromium ferritic Finnish stainless steel, exposed for 30 days in cement extract unbuffered solution in order to simulate the concrete environment at the steel-concretepore interface. Both steels have been proposed as reinforcement in a lower $\mathrm{pH}$ of concrete than the traditional $\mathrm{pH}$ of Portland cement-concrete, in the presence of binders. However, it is very important to first establish the corrosion activity of each steel when $\mathrm{pH}$ in the traditional concrete-pore environment changes in time. Applying a variety of different techniques and methods help to contribute in this aspect. Two non-destructive electrochemical techniques were performed: free corrosion potential monitoring at open circuit potential (OCP) and electrochemical impedance spectroscopy (EIS). The surfaces of the steels were characterized by scanning electron microscopy (SEM) and X-ray photoelectron spectroscopy (XPS) techniques. To our knowledge, no other research on this topic has been previously undertaken.

\section{Materials and Methods}

\subsection{Samples and Solution Preparation}

Flat samples of carbon steel construction material (B450C), supplied by Pittini Group (Gemona del Friuli, Italy), and commercial low chromium ferritic stainless steel (SS 430), 
supplied by Outokumpu (Espoo, Finland), were cut $(2 \mathrm{~cm} \times 1 \mathrm{~cm} \times 0.1 \mathrm{~cm})$, abraded with wet $\mathrm{SiC}$ paper to 4000 grit using ethanol as lubricant, and were then sonicated and dried in air prior to immersion tests. Table 1 presents the elemental composition of the stainless steel and carbon steel.

Table 1. Stainless steel 430 and carbon steel (B450C) compositions (wt.\%), according to suppliers Outokumpu (Finland) and Pittini Group (Italy).

\begin{tabular}{ccccccccc}
\hline $\begin{array}{c}\text { Element } \\
\text { (wt.\%) }\end{array}$ & $\mathbf{C}$ & $\mathbf{C r}$ & $\mathbf{N}$ & $\mathbf{C u}$ & $\mathbf{P}$ & $\mathbf{S}$ & Fe & PRE $^{\mathbf{1}}$ \\
\hline SS 430 & 0.05 & 16.2 & - & - & - & - & Balance & 16 \\
B450C & 0.22 & - & 0.12 & 0.8 & 0.5 & 0.5 & Balance & - \\
\hline
\end{tabular}

${ }^{1}$ PRE (Pitting Resistance Equivalent) value is a common tool in stainless steel design for predicting susceptibility to pitting corrosion $[13,14,39]$, where higher values indicate higher resistance to pitting corrosion. PRE is calculated on the basis of the $\mathrm{Cr}, \mathrm{Mo}, \mathrm{W}$, and $\mathrm{N}$ content of an alloy, and the most common form of PRE is $\mathrm{PRE}=\% \mathrm{Cr}+3.3(\% \mathrm{Mo}+0.5 \% \mathrm{~W})+16 \% \mathrm{~N}$. Other parameters are assumed to be constant, such as surface condition, heat treatment history, possible precipitation of intermetallic phases, inclusion level, grain size, and variation of the surface metallurgy.

The model solution simulates non-carbonated concrete pores and was prepared from 1:1 wt./wt. mixture of Portland cement type I, produced by CEMEX (CEMEX, S.A.B. de C.V., San Pedro Garza García, N.L., México) and ultrapure deionized water $(18.2 \mathrm{M} \Omega \cdot \mathrm{cm})$. Table 2 gives the chemical composition of the cement and that of the cement extract solution after filtration, according to Wang et al. [23]. The mixture was stored for $24 \mathrm{~h}$ in a sealed container in order to allow cement hydration and avoid the absorption of $\mathrm{CO}_{2}$ from the air. Subsequently, the suspended particles were removed from the supernatant by filtering the solution with a $125 \mathrm{~mm}$ pore-size filter paper (Whatman, Kent, UK). The experiments were carried out in the absence of chlorides, because the steel surface in concrete is not usually exposed to $\mathrm{Cl}^{-}$ions during the initial stages. The initial $\mathrm{pH}$ value of this model solution was 13 , and it was regularly checked by a $\mathrm{pH}$ meter during the immersion of the steel samples.

Table 2. Composition of Portland cement according to the producer and chemical analysis of filtered cement extract solution as proposed [23] after $24 \mathrm{~h}$.

\begin{tabular}{ccccc}
\hline Compound & $\begin{array}{c}\text { Portland Cement } \\
\text { Weight } \mathbf{\%}^{\mathbf{2}}\end{array}$ & Weight $\mathbf{\%}^{\mathbf{3}}$ & $\begin{array}{c}\text { Cement Extract } \\
\text { Ion }\end{array}$ & mmol L $^{\mathbf{1}}$ \\
\hline $\mathrm{CaO}$ & $66.84\left(\mathrm{as} \mathrm{Ca}^{2+}\right)$ & 58.42 & $\mathrm{Ca}^{2+}$ & 6.4 \\
$\mathrm{SiO}_{2}$ & 21.35 & 22.30 & $\mathrm{~K}+$ & 35.1 \\
$\mathrm{Al}_{2} \mathrm{O}_{3}$ & $4.87\left(\mathrm{as} \mathrm{Al}^{3+}\right)$ & 4.62 & $\mathrm{SO}_{4}^{2-}$ & - \\
$\mathrm{Fe}_{2} \mathrm{O}_{3}$ & $2.89\left(\mathrm{as} \mathrm{Fe}^{3+}\right)$ & 2.44 & $\mathrm{Na}^{+}$ & 18.3 \\
$\mathrm{SO}_{3}$ & 2.42 & 2.20 & $\mathrm{OH}^{-}$ & 56.4 \\
$\mathrm{MgO}$ & $1.16($ as Mg & - & - \\
$\mathrm{K}_{2} \mathrm{O}$ & 0.39 & 1.92 & - & - \\
$\mathrm{Na}_{2} \mathrm{O}$ & 0.08 & 0.35 & - & - \\
\hline
\end{tabular}

${ }^{2}$ According to this study. ${ }^{3}$ According to [23].

\subsection{Immersion Test and Surface Characterization}

The triplicate steel samples $\left(0.8 \mathrm{~cm}^{2}\right.$ working area) were immersed in $50 \mathrm{~mL}$ of cement extract solution, according to the ASTM G31-12a standard for laboratory immersion corrosion testing of metals [40]. They were withdrawn after $720 \mathrm{~h}$ (30 days), rinsed with deionized water, and dried in air at room temperature $\left(21^{\circ} \mathrm{C}\right)$. The damage on the steel surface was evaluated on removal of the corrosion products formed after exposure for 30 days in cement extract solution. The carbon steel samples were submerged in a solution of hydrochloric acid and hexamethylene tetramine for $10 \mathrm{~min}$ at $21^{\circ} \mathrm{C}$, while SS 430 samples were submerged in a solution of nitric acid and hydrofluoric acid for $5 \mathrm{~min}$ at $21^{\circ} \mathrm{C}$, according to the cleaning procedure recommended by ASTM G1-03 standard [41]. 
Furthermore, their surfaces were characterized by Scanning Electron Microscopy (SEMEDS, XL-30 ESEM-JEOL JSM-7600F, JEOL Ltd., Tokyo, Japan), and the corrosion products were analyzed with an X-ray Photoelectron Spectrometer (XPS, K-Alpha, Thermo Scientific, Waltham, MA, USA) equipped with a monochromatic Al K-alpha radiation source $(1486.6 \mathrm{eV})$. The pass energy was $50 \mathrm{eV}$ and the energy step size was $0.1 \mathrm{eV}$ for the scan of XPS spectra, while for survey spectra, they were $100 \mathrm{eV}$ and $1 \mathrm{eV}$, respectively. The XPS spectra were obtained after sputtering the specimens' surface with a scanning argon-ion gun during $15 \mathrm{~s}$. The spectra were calibrated by setting the main line for the $\mathrm{O} 1 \mathrm{~s}$ signal of oxygen in oxides at $530.2 \mathrm{eV}$, according to the procedures suggested by Yamashita and Hayes for transition metal oxides [42].

\subsection{Electrochemical Measurements}

An Interface-1000E potentiostat/galvanostat/ZRA (Gamry Instruments, Philadelphia, PA, USA) was used for electrochemical experiments, with a typical three-electrode cell configuration inside a Faraday cage. The working electrodes were steel plates $\left(0.8 \mathrm{~cm}^{2}\right)$; the Pt plate was used as an auxiliary, and a saturated calomel electrode (SCE) was the reference electrode. All experiments were carried out at room temperature $\left(21^{\circ} \mathrm{C}\right)$. Electrochemical Impedance Spectroscopy (EIS) measurements were performed at the open circuit potential (OCP), applying an $\mathrm{AC}$ signal of $\pm 10 \mathrm{mV}$ amplitude, in a frequency range from $100 \mathrm{kHz}$ to $10 \mathrm{mHz}$, and with a sampling size of 10 data points/decade. EIS diagrams were recorded at different immersion periods: $10 \mathrm{~min}$ (initial) and 24, 168, 360, 504, and $720 \mathrm{~h}$ (30 days).

\section{Results and Discussion}

\subsection{Steel Surface Characterization}

Figure 1 shows the SEM images of ferritic SS 430 (Figure 1a) and carbon steel B450C (Figure $1 \mathrm{~b}$ ) surfaces of control samples, observed by low-angle backscattered electrons (LABE). The EDS elemental analysis (Table 3) confirms the presence of a high Cr content $(\approx 16 \mathrm{wt} . \%)$ on the ferritic SS 430 surface, which plays an important role in increasing pitting corrosion resistance [7,15], as well as the presence of C (1.94 wt.\%), N (1.14 wt.\%), Mn (0.65 wt.\%), and V (0.28 wt.\%). Generally, Mn is added to stainless steels during melting to assist in de-oxidation and to prevent the formation of S-inclusions, which can cause hot cracking problems. Manganese allows hardness and strength to increase when it forms phases such as $\mathrm{Mn} 3 \mathrm{Cr}$ and nitrides with Nitrogen $(\mathrm{N})$. Vanadium provides a ferrite stabilizing effect, and it is used to help control the grain size of the steel, keeping it small, as stable compounds are formed in steel with Carbon $\left(\mathrm{V}_{6} \mathrm{C}_{5}\right.$, carbide phase) and Nitrogen (VN, nitride phase), which block and prevent the grains from growing larger. Thus, this finer grain structure increases the ductility, hardness, and strength of steel. The existence of carbide phase $(\mathrm{Cr}, \mathrm{Fe})_{7} \mathrm{C}_{3}$ and $\mathrm{Cr}$-nitride have also been reported $[15,43]$.

Table 3. EDS surface analysis (wt.\%) of SS 430 (Figure 2a) and carbon steel B450C (Figure 2b) control samples.

\begin{tabular}{cccccccccccc}
\hline Element & & $\mathbf{C}$ & $\mathbf{C r}$ & $\mathbf{M n}$ & $\mathbf{S i}$ & $\mathbf{O}$ & $\mathbf{V}$ & $\mathbf{C u}$ & $\mathbf{N}$ & $\mathbf{S}$ & $\mathbf{F e}$ \\
\hline \multirow{2}{*}{ SS 430 } & General & 1.83 & 16.32 & 0.65 & 0.6 & 0.34 & 0.28 & - & - & - & 79.97 \\
& A & $\mathbf{3 . 0 4}$ & $\mathbf{2 4 . 0 3}$ & - & 0.25 & 0.62 & 0.7 & - & $\mathbf{3 . 2 7}$ & - & 68.09 \\
& B & $\mathbf{1 7 . 1 9}$ & $\mathbf{9 . 2 1}$ & - & $\mathbf{2 8 . 8 6}$ & 1.35 & - & - & - & - & 43.39 \\
B450C & General & 2.36 & - & 0.81 & - & 0.47 & - & - & - & - & 96.36 \\
& C & $\mathbf{5 . 0 2}$ & - & $\mathbf{1 . 3 1}$ & 0.41 & 1.44 & - & 0.83 & - & $\mathbf{0 . 3 8}$ & 90.36 \\
& D & $\mathbf{8 . 4 9}$ & - & 0.73 & $\mathbf{6 . 4 6}$ & 0.46 & - & - & - & - & 83.85 \\
\hline
\end{tabular}

Note: Even though the surface of both alloys were continuously sonicated after the polishing with SC paper, the higher content of $\mathrm{Si}(\mathrm{SiC})$ on the SS 430 surface is not well understood. Since Si has strong affinity for oxygen, after the polishing process, the outer surface layer was enriched in this element. 

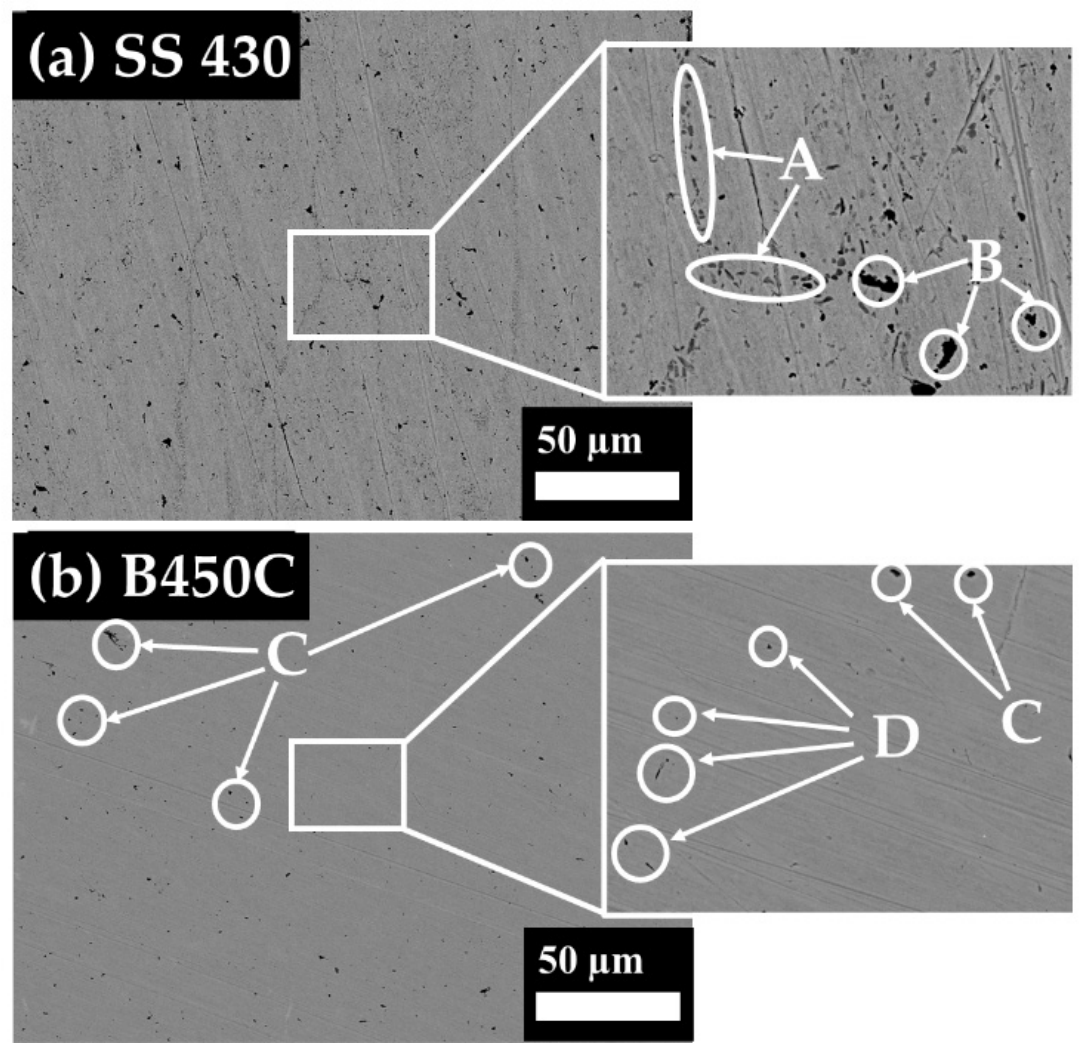

Figure 1. SEM images $(500 \times)$ of surface steel control samples and magnification $(3000 \times)$ of areas of interest: (a) SS 430 and (b) carbon steel B450C.

The SS 430 surface (Figure 1a) presents multiple gray dots (A), whose composition (Table 3) indicates that it is probably of chromium nitride and carbide phases, which typically precipitate at the grain boundaries because of the lower solubility of $\mathrm{C}$ and $\mathrm{N}$, as well as being due to the fast diffusivity of $\mathrm{Cr}$ in the ferrite phase [43]. A small signal of $\mathrm{V}$ is also observed if this metal replaces the $\mathrm{Cr}$ sites in the lattice of $\mathrm{Cr}-\mathrm{C}-\mathrm{N}$ crystal structure, forming precipitates of vanadium carbonitrides $(\mathrm{V}(\mathrm{C}, \mathrm{N}))$ [44]. There is also a darker area (B) that may be attributed to silicon carbide ( $\mathrm{SiC})$.

Carbon steel B450C (Figure 1b) contains as alloying elements mainly carbon (2.36 wt. \%) and manganese (0.81 wt.\%), according to the general chemical analysis EDS (Table 3). Black dots (C) with high Mn and lower sulfur (S) contents were also observed; this could be considered as the MnS phase, which has been reported for this type of steel $[45,46]$. However, due to the high carbon content (2.36 wt.), the phase of Mn3C is probably also present. The existence of $\mathrm{Cu}$ content may be attributed to the quality of the scrap used to produce this carbon steel [46]. Another zone (D) was also analyzed, which appears to be the $\mathrm{SiC}$ phase. Manganese and silicon, although not explicitly reported by the supplier, are always present.

In order to correlate the elemental quantification analysis SEM-EDS (Table 3) with the phases present on the studied steel surfaces, XPS of SS 430 and carbon steel B450C control samples was performed. Figure 2 shows the high-resolution spectra for $\mathrm{Fe}, \mathrm{O}, \mathrm{Cr}$, and Mn. Based on the average of the binding energies [47], the spectra of Fe2p, Cr2p, and O1s signals were deconvoluted into chemical states, as the most probable oxidized and non-oxidized components for corresponding chemical assignments. 
(a)

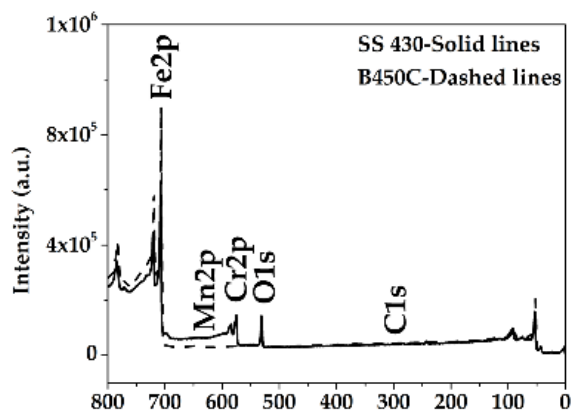

(d)

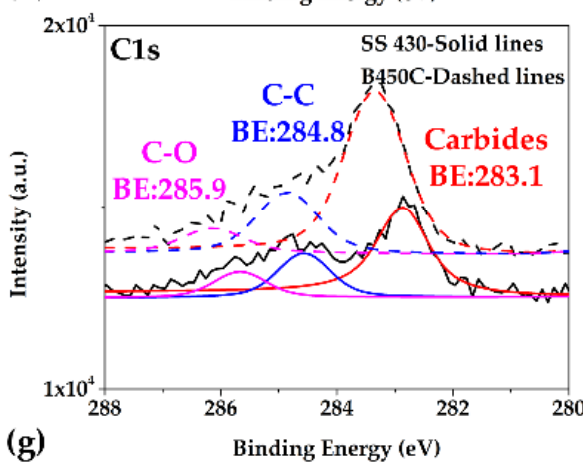

(g)

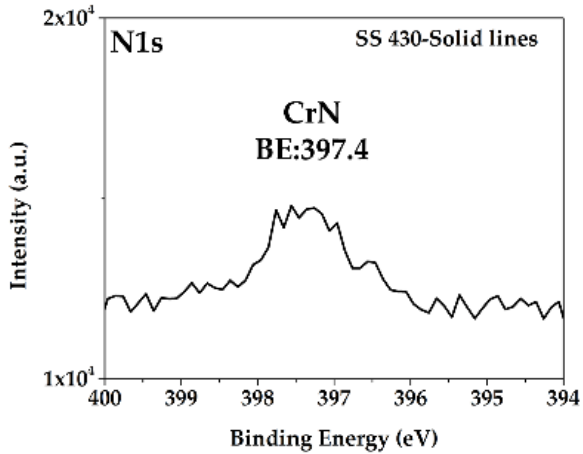

(b)

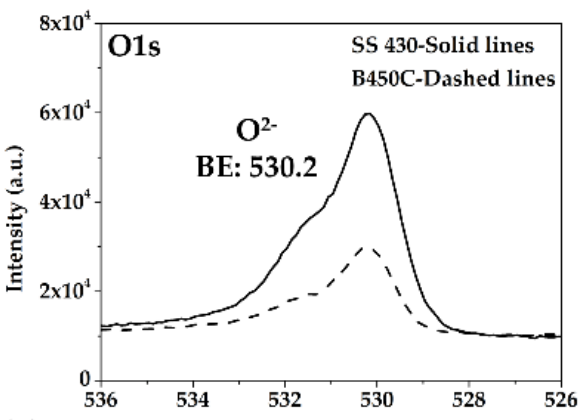

(e)

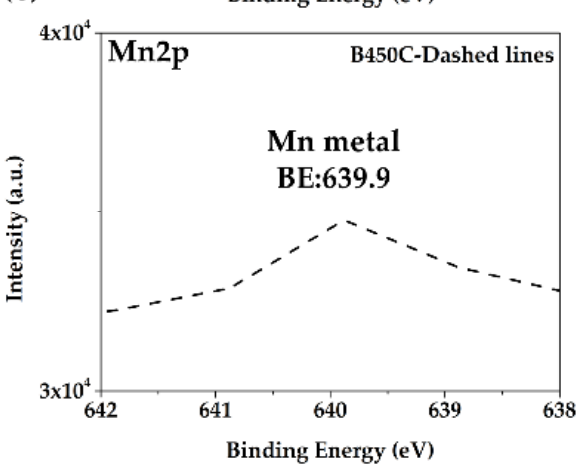

(c)

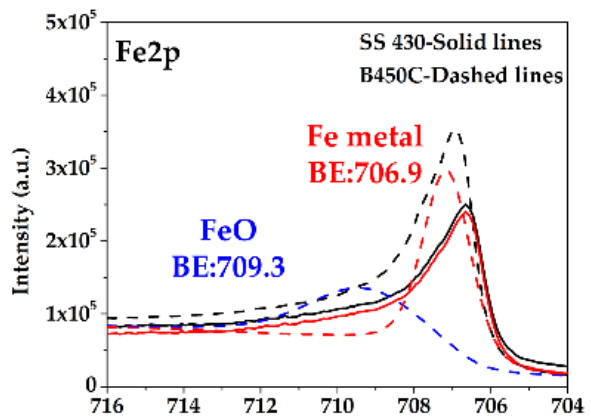

(f)

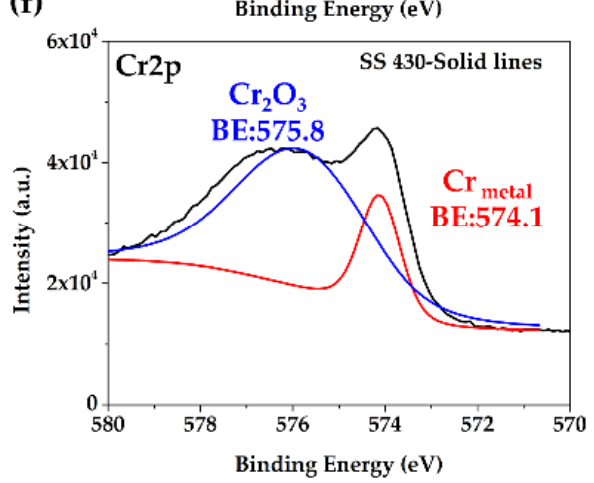

Figure 2. Overview of X-ray photoelectron spectroscopy (XPS) spectra acquired from SS 430 and carbon steel B450C control sample surfaces: (a) full spectrum; spectrum for (b) O1s, (c) Fe2p, (d) C1s, (e) Mn2p, (f) Cr2p, and (g) N1s.

The peaks of Fe (Figure 2c) and $\mathrm{Cr}$ (Figure 2f) were separated into different oxidation states [48]. The displayed peak for O1s corresponding to $\mathrm{O}^{2-}$ was associated with an oxide phase, attributed to $\mathrm{FeO}\left(\right.$ at $709.3 \mathrm{eV}$ ) and $\mathrm{Cr}_{2} \mathrm{O}_{3}$ (at $575.8 \mathrm{eV}$ ), formed on the surfaces in contact with the atmosphere, before the immersion in cement extract model solution. Both steel surfaces also present the Fe2p peak (at $706.9 \pm 0.2 \mathrm{eV}$ ), corresponding to Fe-metal matrix. Furthermore, SS 430 shows the peak of Cr2p (at $574.1 \mathrm{eV}$ ), attributed to $\mathrm{Cr}$ as an alloying element (Figure 2f). Signals with lower intensity of carbon (Figure 2d) and nitrogen (Figure 2g) were also observed, corresponding to $\mathrm{C}-\mathrm{O}$ (at $285.9 \pm 0.2 \mathrm{eV}$ ) and $\mathrm{C}-\mathrm{C}$ (at $284.8 \pm 0.2 \mathrm{eV}$ ) bonds, usually reported as contamination, as well as the signals at $283.1 \pm 0.2 \mathrm{eV}$ and $397.4 \mathrm{eV}$, attributed to carbides and chromium nitrides, respectively [44] The control sample of carbon steel B450C also displayed a very low signal of metallic Mn (Figure 2e, at $639.9 \mathrm{eV}$ ); however, the signals of $\mathrm{S}$ and MnS suggested by EDS were not detected.

\subsection{Steel Surface Characterization after Exposure to Cement Extract Solution}

Figure 3 shows SEM images of the steel surfaces studied after their exposure to the cement extract solution for 168 (7 days) and $720 \mathrm{~h}$ (30 days). The SS 430 surface (Figure 3a) exhibits two different zones (A and B) after $168 \mathrm{~h}$ of immersion. EDS analysis (Table 4) 
suggests that zone $\mathrm{A}$ is associated with the metal matrix, having a slight increase in oxygen content (1.69 wt.\%) with respect to the unexposed surface (Figure 1a and Table 3), and with the presence of traces of $\mathrm{Ca}$. On the other hand, crystals (zone B) with high contents of C (13.75 wt.\%), O (53.8 wt.\%), and Ca (30.22 wt.\%) were deposited on the stainless steel surface, and this analysis suggests the presence of $\mathrm{CaCO}_{3}$ crystals. According to study [49], in neutral and alkaline $\mathrm{pH}$, the $\zeta$-potential of stainless steel surfaces has negative values (between $-49.8 \pm 0.6 \mathrm{mV}$ and $-59.0 \pm 4.2 \mathrm{mV}$ ), and as a consequence positive cations may be attracted, such as $\mathrm{Ca}^{2+}$, present in the cement extract solution (Table 2). Results of employed atomistic simulation indicated that the most stable (001) surfaces of $\mathrm{CaCO}_{3}$ are those of two hydrated phases, monohydrocalcite $\left(\mathrm{CaCO}_{3}-\mathrm{H}_{2} \mathrm{O}\right)$ and Ikaite $\left(\mathrm{CaCO}_{3}-6 \mathrm{H}_{2} \mathrm{O}\right)$, which may exist an alkaline water environment [50]. However, after the longer period of exposure of 30 days (Figure 3c), it seems that most of the $\mathrm{CaCO}_{3}$ crystals (zone B) detached from the SS 430 surface because of their mass. After the shorter period of exposure (168 h), the carbon steel surface of B450C (Figure 3b) showed B zones with crystals, having high content of $\mathrm{O}$ and $\mathrm{Ca}$, attributed to $\mathrm{CaCO}_{3}$ (Table 4). The $\mathrm{C}$ zones seem to represent the matrix of the steel, while the D zones of high O content may attributed to the iron-hydroxides layer, as a corrosion product. An evident change in the B450C morphology is notable in the last period of exposure of 30 days (Figure $3 \mathrm{~d}$ ), when most of the surface is covered by voluminous areas presenting high oxygen and iron content (zones D and E), as corrosion products. Only small areas (zone C) appear to be a part of iron steel matrix.
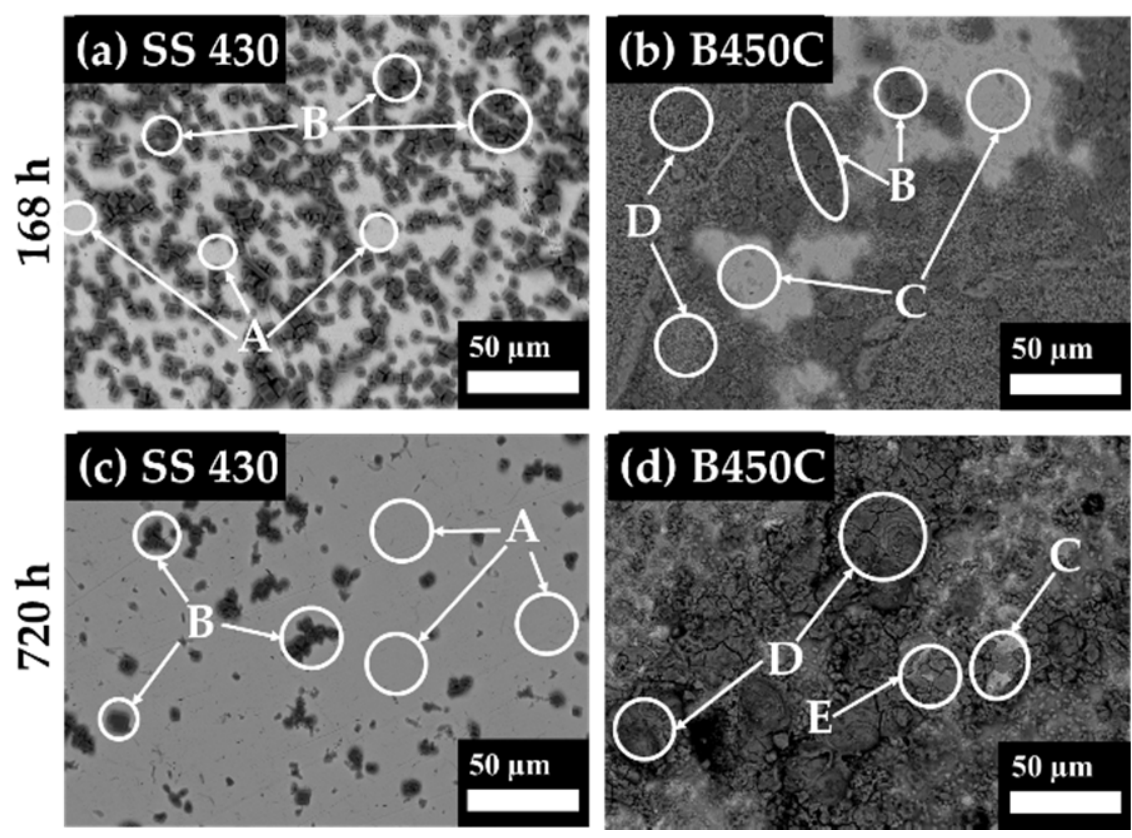

Figure 3. SEM images $(500 \times)$ of steel surfaces after exposure to cement extract solution for $168 \mathrm{~h}$ : (a) SS 430 and (b) carbon steel (B450C); and for 720 h: (c) SS 430 and (d) carbon steel (B450C).

Figure 4 presents the XPS spectra of SS 430 surface exposed for 168 and $720 \mathrm{~h}$. The O1s spectrum (Figure $4 \mathrm{~b}$ ) for both time periods shows contributions from two oxidation states, corresponding to $\mathrm{O}^{2-}$ in oxides (at $530.2 \mathrm{eV}$ ) and $\mathrm{OH}^{-}$in hydroxides (at $531.5 \pm 0.2 \mathrm{eV}$ ), respectively, attributed mainly to $\mathrm{FeO}$ (at $709.3 \pm 0.2 \mathrm{eV}$, Figure $4 \mathrm{c}$ ), $\mathrm{Cr}_{2} \mathrm{O}_{3}$ (at $576.1 \pm 0.1 \mathrm{eV}$ ), and $\mathrm{Cr}(\mathrm{OH})_{3}$ (at $577.7 \pm 0.1 \mathrm{eV}$ ) (Figure 4e). The passive film of SS 430 is mainly composed of $\mathrm{Cr}_{2} \mathrm{O}_{3}$ and $\mathrm{Cr}(\mathrm{OH})_{3}$. Carbon bonds (Figure $4 \mathrm{~d}$ ) may present the $\mathrm{CO}_{3}{ }^{2-}$ ion, as a part of $\mathrm{CaCO}_{3}$ when the signal of Ca2p is registered (Figure $4 \mathrm{f}$ ). 
Table 4. EDS surface analysis (wt.\%) of SS 430 and carbon steel B450C after exposure to cement extract solution for $168 \mathrm{~h}$ (7 days) and $720 \mathrm{~h}$ (30 days).

\begin{tabular}{|c|c|c|c|c|c|c|c|c|c|c|}
\hline Elemen & & & C & $\mathrm{Cr}$ & Mn & Si & $\mathrm{O}$ & $\mathrm{Ca}$ & $\mathrm{Cu}$ & $\mathrm{Fe}$ \\
\hline \multirow{4}{*}{$\begin{array}{c}\text { SS } \\
430\end{array}$} & \multirow{2}{*}{$168 \mathrm{~h}$} & A & 2.87 & 16.84 & - & - & 1.69 & 0.8 & - & 77.8 \\
\hline & & B & 13.75 & - & - & - & 53.8 & 30.22 & - & 2.49 \\
\hline & \multirow{2}{*}{$720 \mathrm{~h}$} & A & 1.81 & 16.43 & - & 0.44 & 1.06 & - & - & 80.01 \\
\hline & & B & 13.75 & 4.62 & - & 0.37 & 32.87 & 21.3 & - & 20.92 \\
\hline \multirow{6}{*}{ B450C } & \multirow{3}{*}{$168 \mathrm{~h}$} & B & 9.1 & - & 0.73 & - & 47.88 & 27.76 & - & 15.27 \\
\hline & & $\mathrm{C}$ & 6.43 & - & 0.67 & - & 7.57 & 0.85 & - & 84.48 \\
\hline & & $\mathrm{D}$ & 4.54 & - & 1.43 & 0.27 & 47.51 & 3.73 & - & 42.51 \\
\hline & \multirow{3}{*}{$720 \mathrm{~h}$} & $\mathrm{C}$ & 4.06 & - & 0.73 & 0.26 & 8.65 & - & 0.97 & 85.33 \\
\hline & & $\mathrm{D}$ & 3.29 & - & 0.36 & - & 44.1 & - & - & 52.26 \\
\hline & & E & 3.09 & 0.24 & 0.27 & 0.41 & 41.98 & - & 0.84 & 53.15 \\
\hline
\end{tabular}

(a)

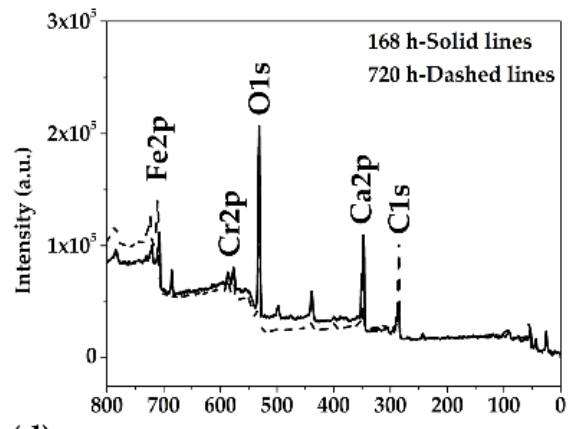

(d)

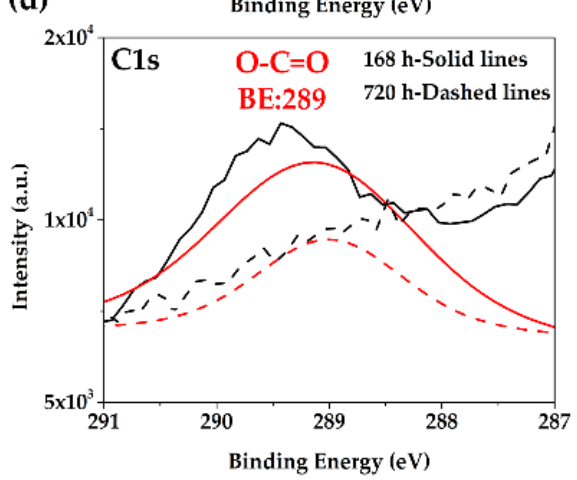

(b)

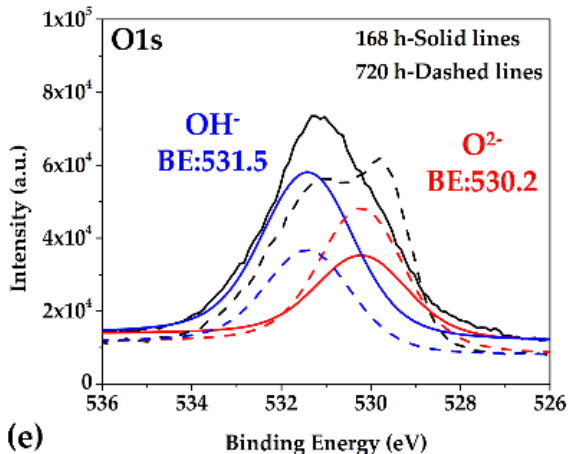

(e)

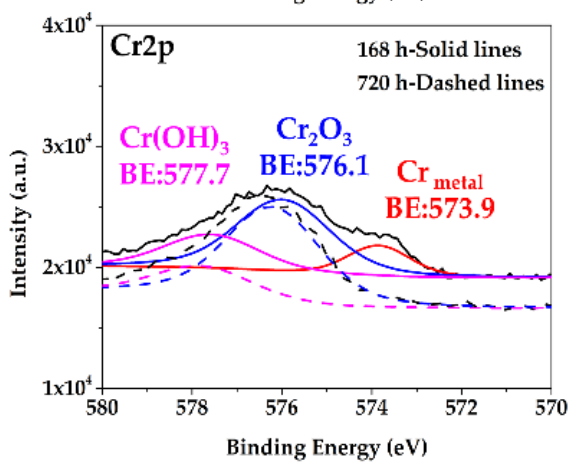

(c)

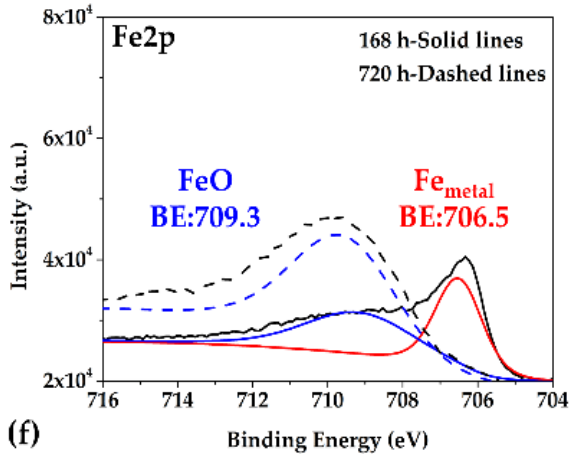

(f)

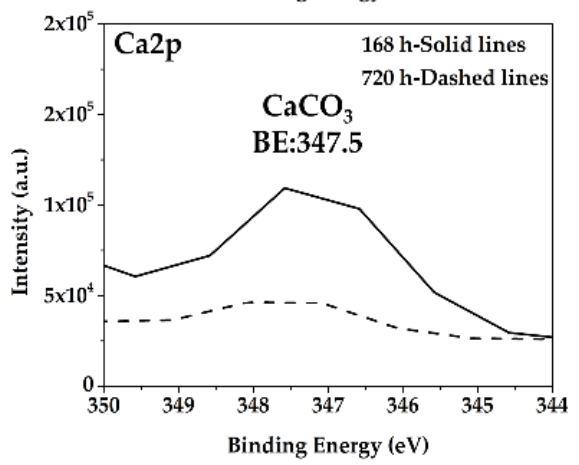

Figure 4. Overview of X-ray photoelectron spectroscopy (XPS) spectra acquired from SS 430 surface after $168 \mathrm{~h}$ and $720 \mathrm{~h}$ of exposure to cement extract solution: (a) full spectrum; spectrum for (b) O1s, (c) Fe2p, (d) C1s, (e) Cr2p, and (f) Ca2p.

The XPS spectra of B450C carbon steel exposed for 168 and $720 \mathrm{~h}$ in cement extract solution (Figure 5) similarly present the oxygen binding energies corresponding to $\mathrm{O}^{2-}$ in oxides (at $530.2 \mathrm{eV}$ ) and $\mathrm{OH}^{-}$in hydroxides (at $531.5 \pm 0.2 \mathrm{eV}$ ), respectively (Figure $5 \mathrm{~b}$ ). They are attributed mainly to $\mathrm{FeO}($ at $709.7 \pm 0.1 \mathrm{eV})$ and $\mathrm{FeOOH}($ at $711.7 \pm 0.1 \mathrm{eV}$ ), whose signals are observed in Figure $5 \mathrm{c}$, as well as to $\mathrm{MnO}$ (at $641 \mathrm{eV}$ ), representing the signal of Mn2p (Figure 5e). Carbon bonds (Figure 5d) may indicate the $\mathrm{CO}_{3}{ }^{2-}$ ion, as a part of $\mathrm{CaCO}_{3}$ when the signal of $\mathrm{Ca} 2 \mathrm{p}$ is registered (Figure $5 \mathrm{f}$ ). 
(a)

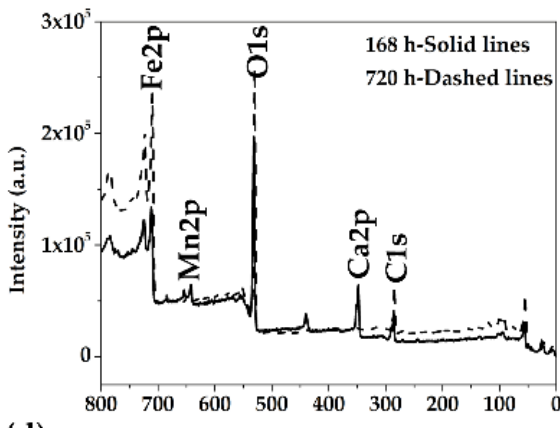

(d)

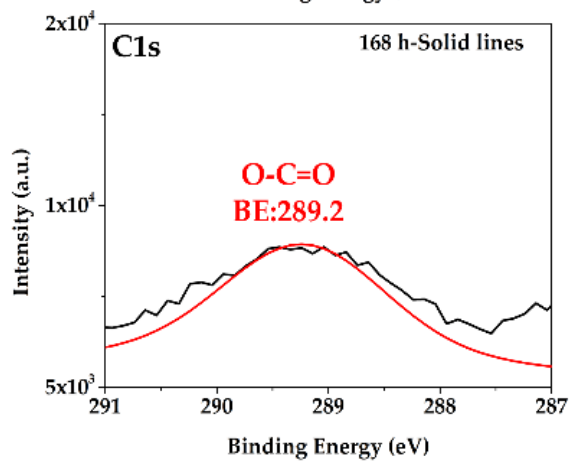

(b)

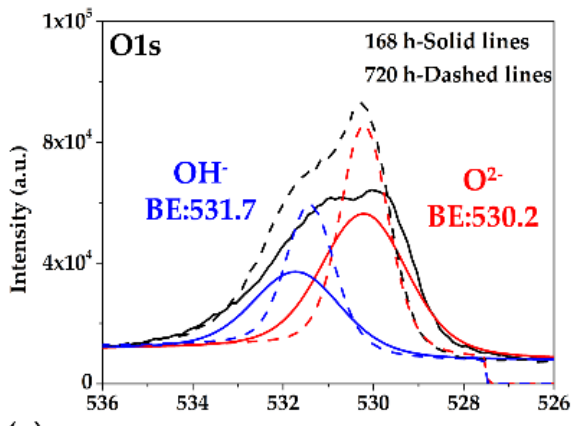

(e)

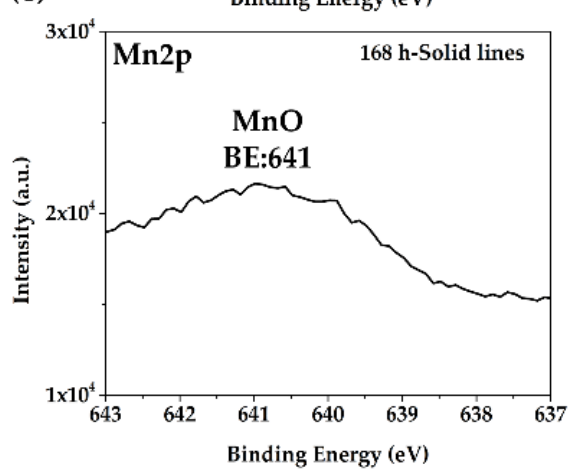

(c)

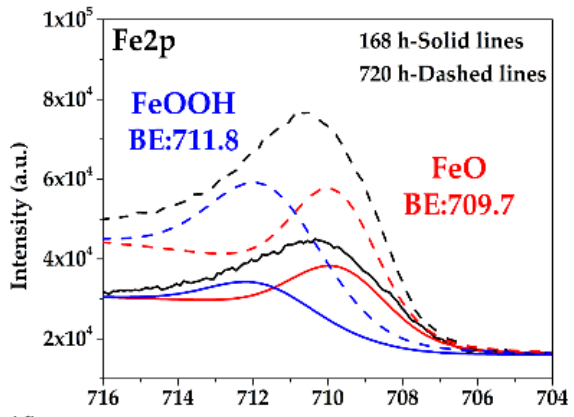

(f)

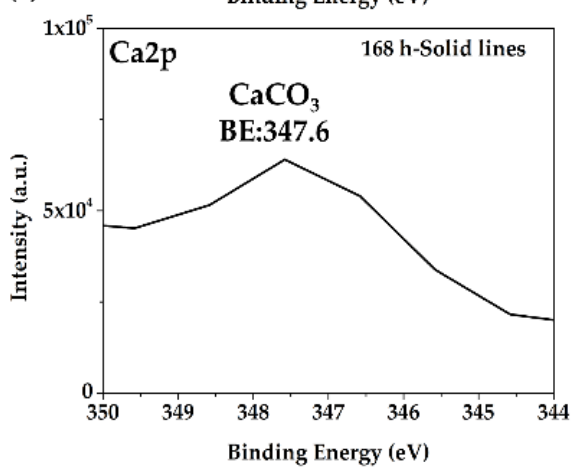

Figure 5. Overview of X-ray photoelectron spectroscopy (XPS) spectra acquired from carbon steel (B450C) surface after 168 $\mathrm{h}$ and $720 \mathrm{~h}$ of exposure to cement extract solution: (a) full spectrum; spectrum for (b) O1s, (c) Fe2p, (d) C1s, (e) Mn2p, and (f) $\mathrm{Ca} 2 \mathrm{p}$.

It may be concluded that the XPS registered spectra correlate well with the EDS-SEM analysis corresponding to both steels.

After the removal of the corrosion layers (Figure 6), two different particles in elemental composition were observed on the studied alloys. On the SS 430 steel surface, the particles (F in Figure 6a and Table 5), having high content of Cr, N, C, and V and which were also present initially on this surface (Figure 1 and Table 3 ), suggested $\mathrm{Cr}-\mathrm{C}-\mathrm{N}$ crystal structure, forming precipitates of vanadium carbonitrides $\mathrm{V}(\mathrm{C}, \mathrm{N})$ [44]. In the meantime, on the carbon steel B450C surface, particles (G) with high $\mathrm{Mn}, \mathrm{Cu}$, and S contents, are present, as reported by the supplier and observed previously (Figure $1 \mathrm{~b}$ and Table 3).
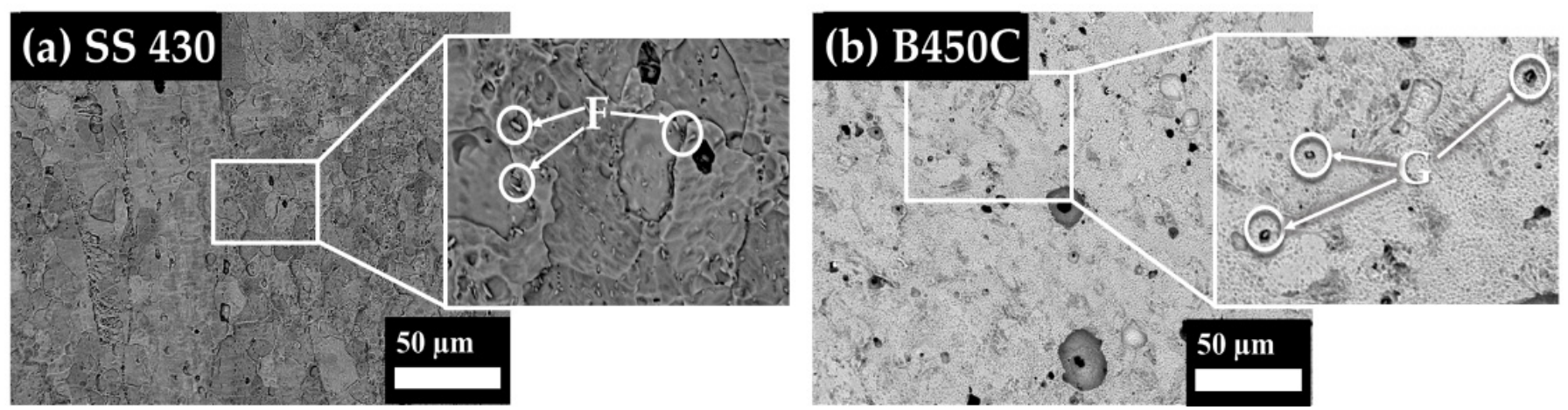

Figure 6. SEM images $(500 \times)$ of steel surfaces after removal of corrosion layers formed during exposure to cement extract solution for 720 h: (a) SS 430 and magnification $(3000 \times)$; (b) B450C and magnification $(1500 \times)$. 
Table 5. EDS surface analysis (wt.\%) of SS 430 and carbon steel B450C after removal of corrosion layers formed during exposure to cement extract solution for $720 \mathrm{~h}$.

\begin{tabular}{ccccccccccc}
\hline Element & & C & Cr & Mn & O & V & Cu & N & S & Fe \\
\hline SS & F & $\mathbf{8 . 2 2}$ & $\mathbf{4 3 . 1}$ & - & - & $\mathbf{1 . 6 5}$ & - & $\mathbf{1 3 . 5 4}$ & - & 33.5 \\
430 & G & 3.98 & - & $\mathbf{3 0 . 5 4}$ & 1 & - & 4.64 & - & $\mathbf{1 0 . 4 2}$ & 49.44 \\
\hline
\end{tabular}

Reported study [51] suggests that, according to the position in the galvanic series (potential values), the iron/steel would present anodic activity, while the trace metals, such as $\mathrm{V}$ (as precipitated $\mathrm{V}(\mathrm{C}, \mathrm{N})$ carbonitrides), would be cathodic active areas. The following reactions are proposed, in addition to the cathodic reaction of $\mathrm{O}_{2}$ reduction (Equation (1)):

$$
\begin{gathered}
\mathrm{Fe} \rightarrow \mathrm{Fe}^{2+}+2 \mathrm{e}^{-} \text {, anodic reaction } \\
\mathrm{V}^{+}+\mathrm{e}^{-} \rightarrow \mathrm{V} \text {, cathodic reaction }
\end{gathered}
$$

It is also considered that the inclusion of MnS does not dissolve when the localized corrosion (pitting) initiates; however, the dissolution of the iron matrix occurs from the immediate surroundings of these inclusions, which may give rise to the initiation and development of pits [52], reaching large size and depth. At the later stages, in the presence of local acidification $\left(\mathrm{H}^{+}\right), \mathrm{MnS}$ may begin to dissolve (Equation (4)). The concentration increase of $\mathrm{H}_{2} \mathrm{~S}$ in turn may contribute locally to additional cathodic processes (Equation (5)), and both reactions (Equations (3) and (5)) will accelerate the anodic dissolution (corrosion) of Fe (Equation (2)) [52].

$$
\begin{gathered}
\mathrm{MnS}+2 \mathrm{H}^{+} \rightarrow \mathrm{H}_{2} \mathrm{~S}+\mathrm{Mn}^{2+}, \text { anodic reaction } \\
2 \mathrm{H}_{2} \mathrm{~S}+2 \mathrm{e}^{-} \rightarrow 2 \mathrm{HS}^{-}+2 \mathrm{H}_{2} \text {, cathodic reaction }
\end{gathered}
$$

\subsection{Change in Time of $\mathrm{pH}$ of Cement Extract Solution during Exposure of Steel Samples}

Figure 7 presents the change in time of $\mathrm{pH}$ of the cement extract solutions during the exposure of SS 430 and carbon steel B450C samples for $720 \mathrm{~h}$ (30 days). The initial value of $\mathrm{pH}=13$ was kept approximately constant up to $168 \mathrm{~h}$ (7 days), decreasing abruptly to $\mathrm{pH} 9$, and maintaining almost this value until the end of the experiment $(720 \mathrm{~h})$. The decrease in $\mathrm{pH}$ may be due primarily to the fact that carbon dioxide from the environment dissolved in the electrolyte, the volume of which is $50 \mathrm{~mL}$ in this experiment, promoting the formation of carbonic acid $\left(\mathrm{H}_{2} \mathrm{CO}_{3}\right)$ [19]. It is considered that for $7<\mathrm{pH}<10$, the $\mathrm{HCO}_{3}{ }^{-}$ions are the predominate species, which are corrosive to metals; thus iron releases ions $\left(\mathrm{Fe}^{2+}\right)$ that attract the $\mathrm{OH}^{-}$from the medium, mainly forming iron hydroxide II [53], which further lowers the $\mathrm{pH}$.

\subsection{Change in Time of Corrosion Potential (OCP) of SS 430 and Carbon Steel (B450C) during Exposure in Cement Extract Solution}

Figure 8 presents the change in time of the average values of corrosion potential (open circuit, OCP, vs. SHE) of SS 430 and carbon steel (B450C) samples during their exposure for $720 \mathrm{~h}$ (30 days) in cement extract solution. The initial values are negative, between $-192 \mathrm{mV}$ (SS 439) and $-150.2 \mathrm{mV}$ (carbon steel B450C), showing a tendency to shift to less negative (positive) values and indicating the formation of passive layers on both steel surfaces. However, after $168 \mathrm{~h}$, when $\mathrm{pH}$ of the electrolyte decreased abruptly to 9, the OCP of the carbon steel returned suddenly to a very negative value $(-450 \mathrm{mV}$, above the initial one) until the end of the experiment ( 30 days), because the surface lost passivity state at a $\mathrm{pH}$ lower than 12. According to the Pourbaix diagram, the iron $(\mathrm{Fe})$ is susceptible to corrosion when the $\mathrm{pH}$ value is below 11.5 [17]. On the other hand, the OCP of SS 430 continued reaching more positive values (Figure 8), even the $\mathrm{pH} 9$, as an indication that the steel maintained its the passive state, contributed mainly to chromium $(\mathrm{Cr})$ as alloying element. 
Chromium migrates to the SS surface, reacting with the dissolved air oxygen in the water, and $\mathrm{Cr}$-oxide is formed. A surface having enough $\mathrm{Cr}$-reach sites develops very thin layers of a few atoms, creating the passive state on the SS surface $[13,14,39]$.

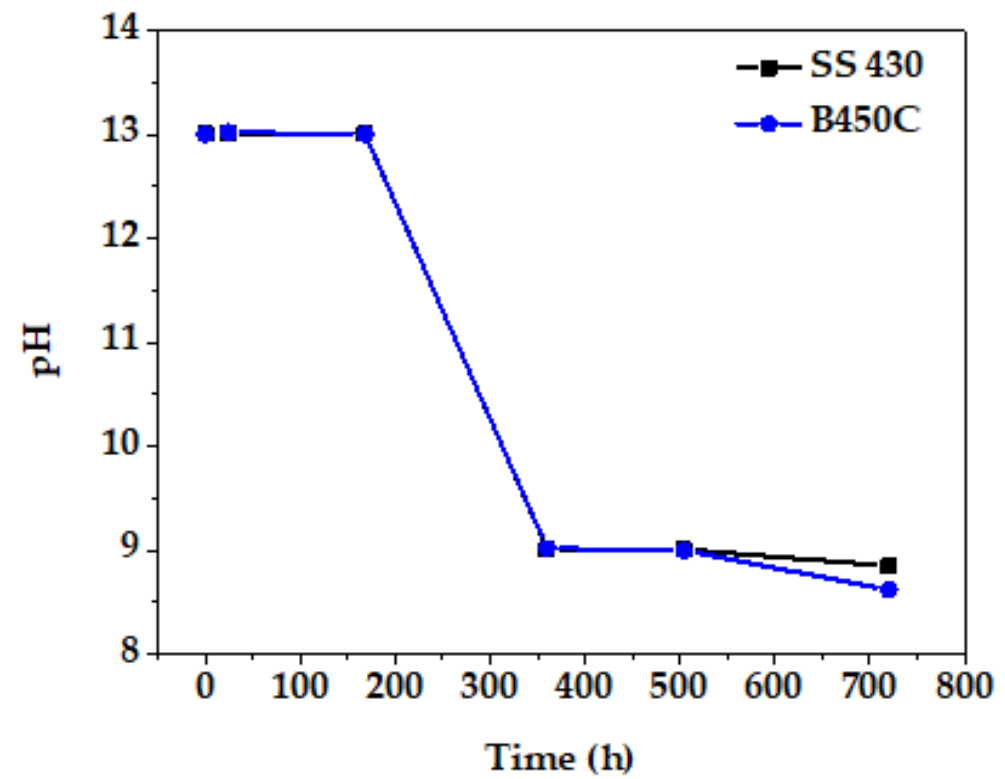

Figure 7. Change in time of $\mathrm{pH}$ cement extract solutions during the immersion of SS 430 and carbon steel B450C samples for $720 \mathrm{~h}$ (30 days).

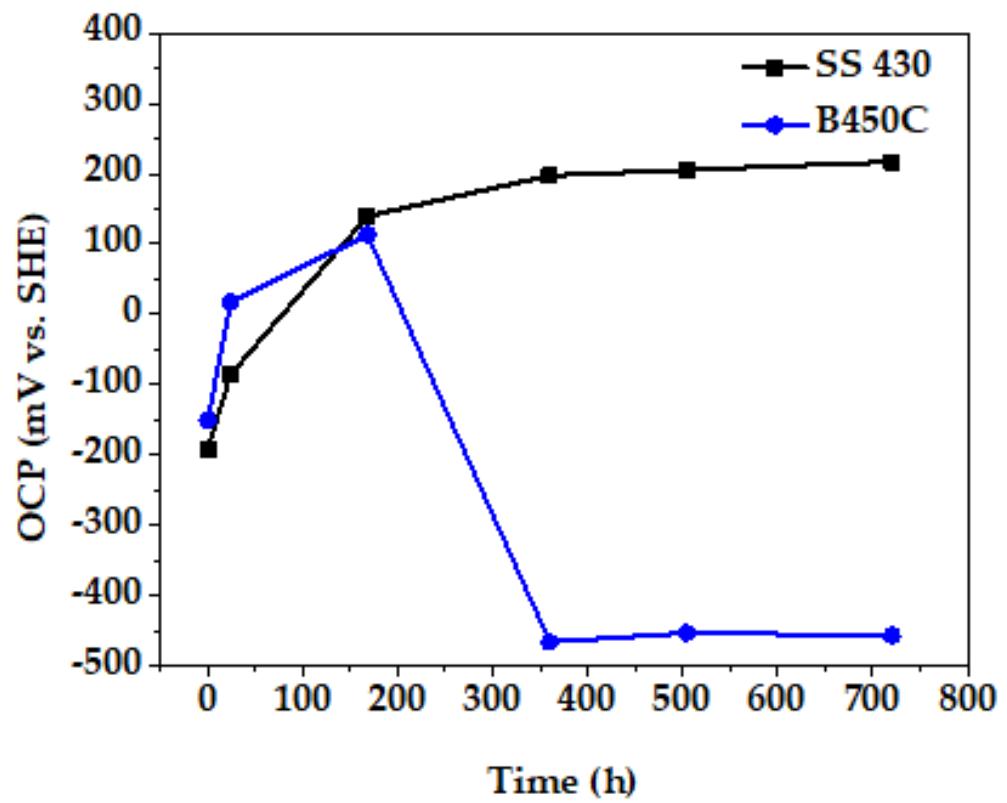

Figure 8. Change in time of open-circuit potential values ( $\mathrm{mV}$ vs. SHE) of SS 430 and carbon steel B450C samples immersed in cement extract model solution (at $22^{\circ} \mathrm{C}$ ) up to $720 \mathrm{~h}$ (30 days).

\subsection{Electrochemical Measurements}

Electrochemical Impedance Spectroscopy (EIS)

Figures 9 and 10 present Nyquist and Bode EIS diagrams for SS 430 and carbon steel B450C samples exposed for different periods (up to $720 \mathrm{~h}$ ) to cement extract solution. The Nyquist plots (Figure 9) show that, at initial time of exposure, each steel presents capacitive behavior, usually attributed to charge transfer and mass transport. However, after the first $24 \mathrm{~h}$, the behavior changes to semi-linear diffusion impedance, caused by inductive 
reactance of the metallic surface, and a linear slope with an angle of $a \approx 45^{\circ}$ is observed. This is associated with diffusion control of the corrosion process, because of the passive films formed on steel surfaces.

(a)

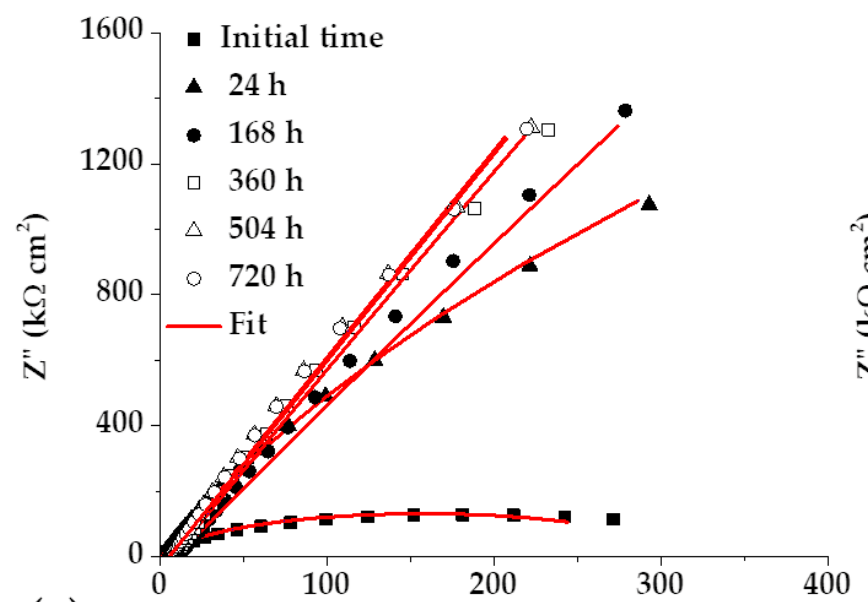

(c)

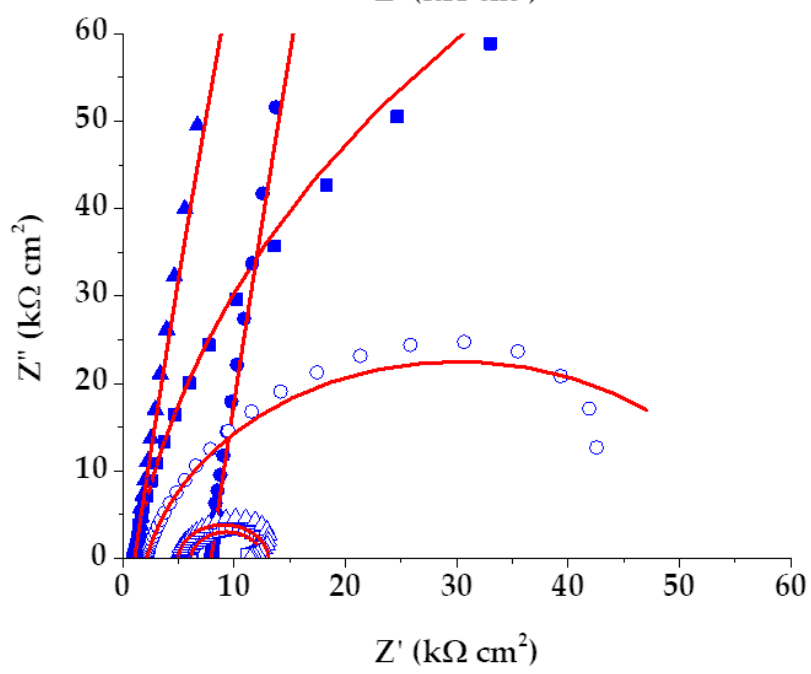

(b)

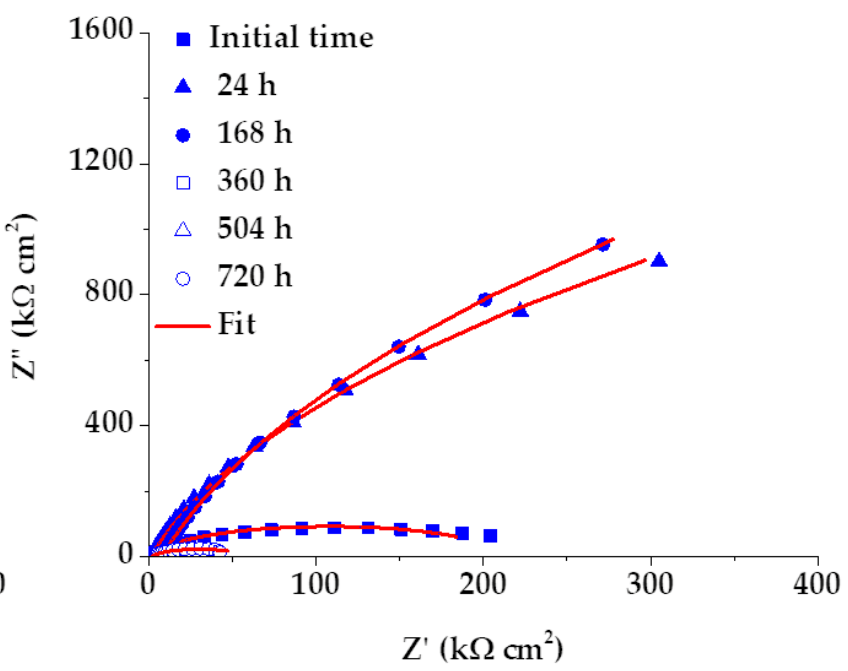

Figure 9. EIS Nyquist diagrams with respective fitting line for SS 430 and carbon steel B450C after different times of immersion in cement extract solution: (a) SS 430, (b) B450C, and (c) magnification of B450C (b) diagram.

The increase of the positive corrosion potential (OCP) values of SS 430 (Figure 8) indicate that the passive state is not influenced by the changes in $\mathrm{pH}$ of the cement extract solution (Figure 7). Thus, the immersion time of SS 430 improves its the corrosion resistance, maintaining firmly the diffusion impedance until the end of the experiment (Figure 9a), as typical for passivated stainless steel surfaces $[48,54]$. On the other hand, the carbon steel B450C keeps the diffusion impedance no longer than $168 \mathrm{~h}$ (Figure 9b) and when the passive state is lost a return to capacitive behavior is observed, because of the decrease of the $\mathrm{pH}$ (Figure 7). Consequently, the carbon steel displays semi-circles, whose diameter decreases with the time of immersion (Figure 9c). 
(a)

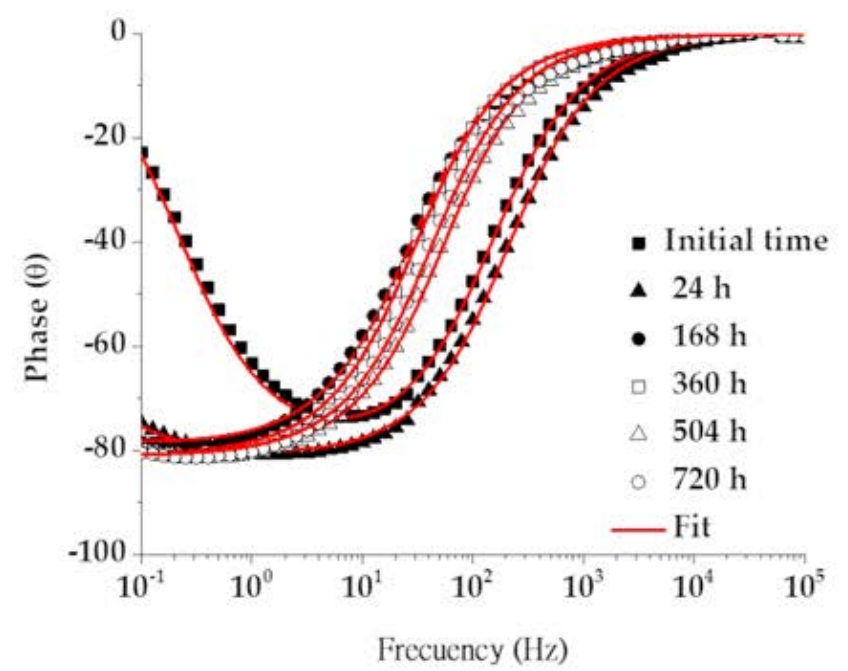

(b)

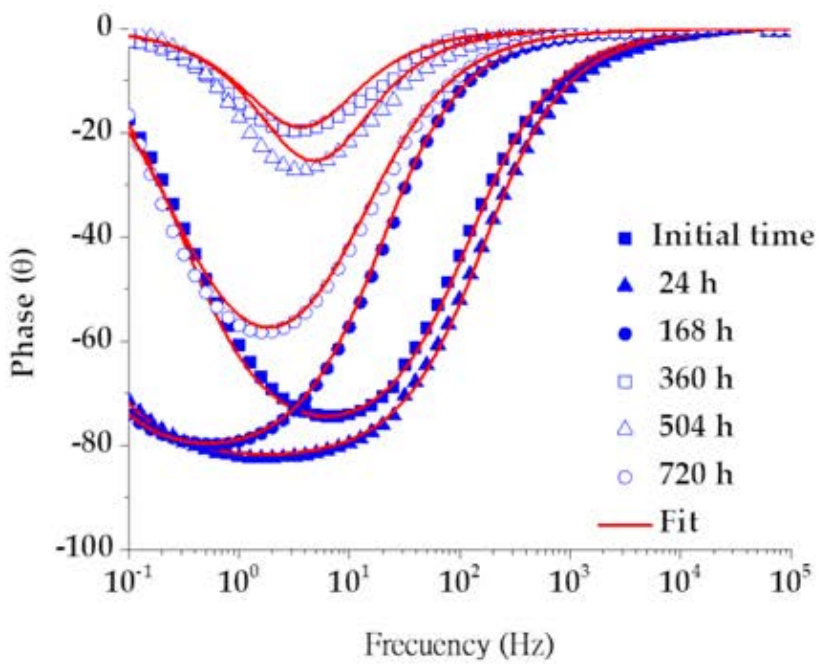

Figure 10. EIS Bode diagrams-Phase angle with respective fitting line for SS 430 and carbon steel B450C after different times of immersion in cement extract solution: (a) SS 430, (b) B450C.

The changes in the behavior of the Nyquist diagrams of the steels during immersion in cement extract solution are confirmed by the phase angle Bode diagrams (Figure 10). It may be seen that the SS 430 keeps an angle $\approx-80^{\circ}$ until the end of the experiment (Figure 10a), while the carbon steel (Figure 10b) showed a tendency toward very low angles, which generally characterize capacitive surfaces [54]. A phase angle of $-90^{\circ}$ indicates an electrode interface that is capable of accumulating electrical charges, avoiding migration of aggressive species like $\mathrm{O}^{2-}$ and $\mathrm{Cl}^{-}$from the solution through interface, as also providing a high resistance to the corrosion process development, usually because of an existing stable and almost perfect passive surface layer [54-56].

Equivalent circuits (ECs) were proposed (Figure 11) to investigate the EIS data further. The first EC consists of a simplified Randles circuit (Figure 11a), where $R_{S}$ corresponds to the resistance of the electrolyte, $C P E_{2}$ is the capacitance of the double layer of the electrolyte/electrode interface, and $\mathrm{R}_{\mathrm{ct}}$ is the charge transfer resistance of the film. This type of model describes the electrochemical reactions of a passive system with only one time constant, which is consistent with other work regarding carbon steel in alkaline solutions $[5,28]$. The second proposed circuit (Figure 11b) has been used to fit different types of stainless steel in alkaline solutions [57-59]. The circuit is composed of a resistance at high frequencies, associated with the resistance of the solution $\left(R_{s}\right)$. The resistance $\left(R_{c p}\right)$ and capacitance $C P E_{1}$ are associated with the layers of passive $\mathrm{Cr}_{2} \mathrm{O}_{3} / \mathrm{Cr}(\mathrm{OH})_{3} / \mathrm{FeO}$ films and their hydroxide corrosion products. On the other hand, the resistance $\left(R_{c t}\right)$ is associated with charge transfer resistance of the corrosion process and a capacitance $C P E_{2}$ related to the double capacitive layer in the corrosion-localized area. To obtain a better fit, capacitors may be replaced by constant phase elements (CPEs), which have an exponential factor, $n$, in the range from 0 to 1 , where $n=1$ for an ideal capacitor and $n=0$ for an ideal resistor [57].

It can be noted (Table 6) that the $R_{\text {sol }}$ value increases over time, and one can speculate that this fact is closely related to the diminishing in time of $\mathrm{pH}$ of the cement extract solution (Figure 7). Therefore, a change of ion composition occurs at the interface metal/solution, because of more significant release of iron ions $\left(\mathrm{Fe}^{2+}\right)$, as also appearance of $\mathrm{HCO}_{3}{ }^{-}$ions after the dissolution of $\mathrm{CO}_{2}$ from air and an increase of $\mathrm{H}_{2} \mathrm{~S}$ concentration (Equation (4)). 
(a)

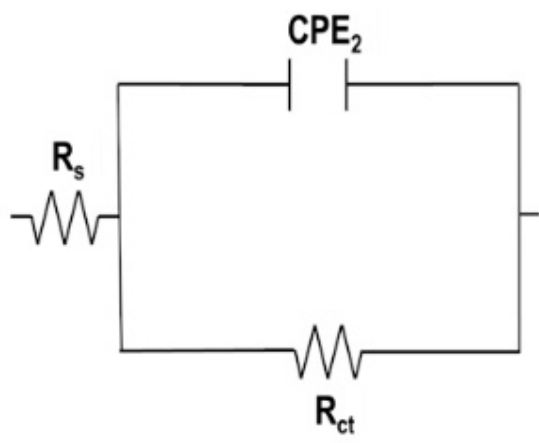

(b)

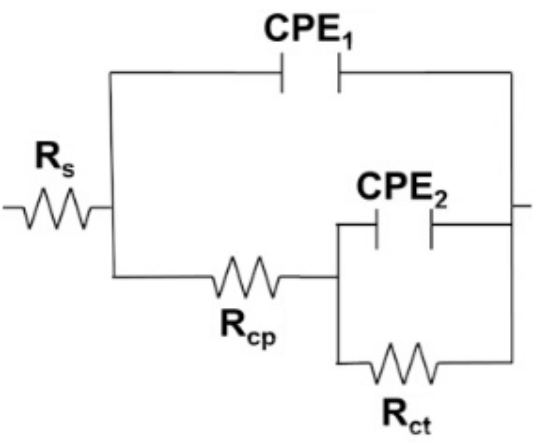

Figure 11. Equivalent circuits proposed for (a) carbon steel B450C and (b) SS 430.

Table 6. Fitting parameters obtained from the EIS measurements.

\begin{tabular}{|c|c|c|c|c|c|c|c|c|c|c|}
\hline & $\underset{\mathrm{h}}{\mathrm{Time}}$ & $\begin{array}{c}R_{\text {sol }} \\
\mathrm{k} \Omega \mathrm{cm}^{2}\end{array}$ & $\begin{array}{c}R_{c p} \\
\mathrm{k} \Omega \mathrm{cm}^{2}\end{array}$ & $\begin{array}{c}C P E_{1} \\
\mu S \mathrm{~s}^{\mathrm{n}} \mathrm{cm}^{-2}\end{array}$ & $\mathrm{n}_{1}$ & $\begin{array}{c}R_{c t} \\
\mathrm{k} \Omega \mathrm{cm}^{2}\end{array}$ & $\begin{array}{c}C P E_{2} \\
\mu S \mathrm{~s}^{\mathrm{n}} \mathrm{cm}^{-2}\end{array}$ & $\mathbf{n}_{2}$ & $\begin{array}{c}R_{p} \\
\mathrm{k} \Omega \mathrm{cm}^{2}\end{array}$ & $\begin{array}{c}c^{2} \\
10^{-4}\end{array}$ \\
\hline \multirow{6}{*}{ SS 430} & 0.5 & 0.99 & 0.04 & 74.24 & 0.88 & 312.88 & 27.99 & 0.89 & 312.91 & 6.11 \\
\hline & 24 & 1.15 & 1.99 & 285.75 & 1.00 & 10,766 & 16.54 & 0.90 & 10,768 & 3.23 \\
\hline & 168 & 9.39 & 2.50 & 111.65 & 1.00 & 172,630 & 13.23 & 0.88 & 172,630 & 10.1 \\
\hline & 360 & 7.65 & 2238.8 & 0.20 & 1.00 & 375,630 & 14.41 & 0.90 & 377,860 & 4.42 \\
\hline & 504 & 4.45 & 0.94 & 314.38 & 1.00 & $1,570,000$ & 14.58 & 0.90 & $1,570,000$ & 6.63 \\
\hline & 720 & 5.54 & $4,741,300$ & 0.04 & 1.00 & $8,997.5$ & 14.59 & 0.90 & $4,750,200$ & 7.90 \\
\hline \multirow{6}{*}{ B450C } & 0.5 & 0.95 & - & - & - & 213.50 & 32.05 & 0.91 & 213.50 & 8.24 \\
\hline & 24 & 1.05 & - & - & - & 4766.3 & 20.39 & 0.93 & 4766.3 & 3.00 \\
\hline & 168 & 7.91 & - & - & - & 6331.3 & 19.65 & 0.93 & 6331.3 & 2.55 \\
\hline & 360 & 6.08 & - & - & - & 6.53 & 156.63 & 0.95 & 6.53 & 12.6 \\
\hline & 504 & 4.96 & - & - & - & 8.15 & 107.95 & 0.96 & 8.15 & 22.0 \\
\hline & 720 & 2.12 & - & - & - & 55.90 & 128.00 & 0.86 & 55.90 & 8.62 \\
\hline
\end{tabular}

The values of the fitting parameters obtained from the EIS measurements are presented in Table 6 and their fit $\mathbf{c}^{2}\left(10^{4}\right)$ was good in the most cases.

The polarization resistance $\left(R_{p}\right)$ values over time (Table 6) were calculated using the following equation [48]:

$$
R_{p}=R_{c p}+R_{c t}
$$

The values of $R_{p}$ for SS 430 increase over time, as an indication that the passive layer on its surface seems to be highly protective, mainly due to $\mathrm{Cr}_{2} \mathrm{O}_{3}$. For carbon steel, $R_{p}$ reaches its maximum value after $168 \mathrm{~h}$ and then decreases to minimum values, slightly changing until the end of the experiment.

Figure 12 presents the evolution of the passive layer thicknesses $(d)$ with the immersion time. For the $d$ calculation, the $C P E_{2}$ values were used, transformed into the corresponding capacitance values according to the Brug formula (Equation (7)) [54]. The thickness was calculated from Equation (8) [60], where $\varepsilon_{0}$ is the vacuum permittivity $\left(8.85 \times 10^{-14} \mathrm{~F} \mathrm{~cm}^{-1}\right)$ and $\varepsilon$ is the dielectric constant of the passive film, which can be assumed as 15.6 for stainless steels $[61,62]$.

$$
\begin{gathered}
C=C P E^{\frac{1}{n}}\left(\frac{R_{s} R_{c t}}{R_{s}+R_{c t}}\right)^{\frac{1-n}{n}} \\
d=\frac{\varepsilon \varepsilon_{0} A}{C}
\end{gathered}
$$




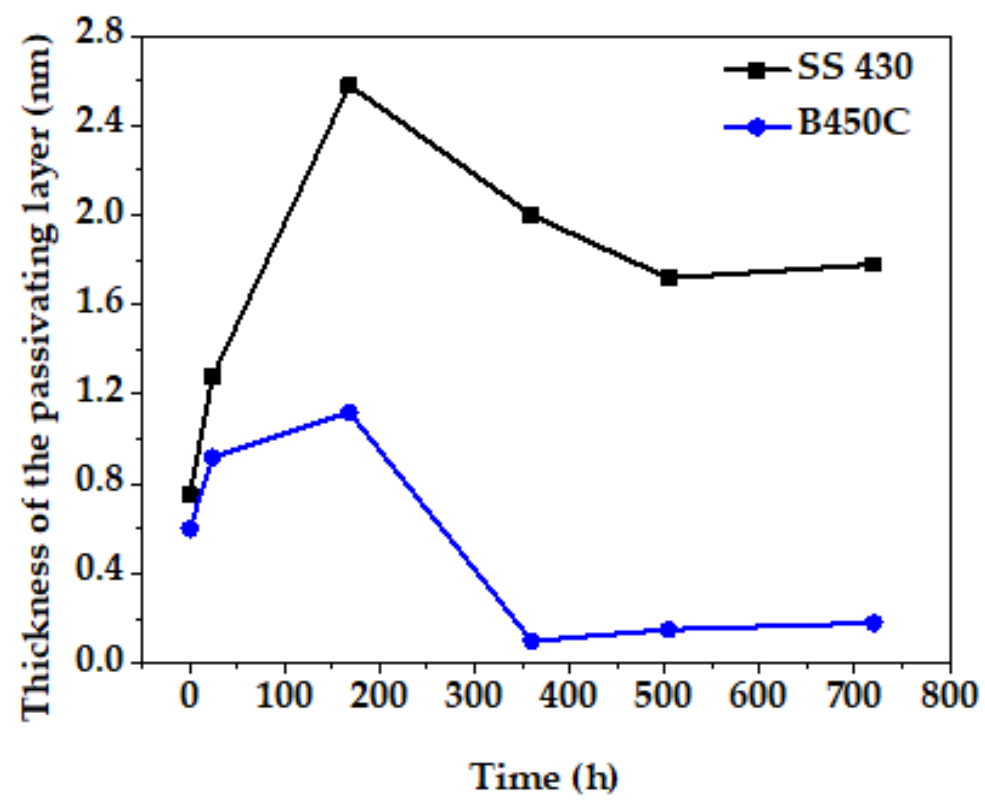

Figure 12. Passive layer thickness (d) evolution in the immersion time for SS 430 (black) and carbon steel B450C (blue).

The calculated values of thickness $(d)$ revealed that they depend on the exposure time and the steel nature (Figure 12). For stainless steel 430, the thickness of the passive layer stabilizes at approximately $2 \mathrm{~nm}$ and remains at about this value until the end of the test (30 days). The passive film thickness values are similar to other values reported for the passive film formed on stainless steels exposed to low chloride content in solutions $(0.5-6 \mathrm{~nm})$; austenitic stainless steel (sanicro28) in $50 \mathrm{wt} . \% \mathrm{H}_{3} \mathrm{PO}_{4}$; $\mathrm{SS} 316 \mathrm{~L}$ in $0.1 \mathrm{M}$ and $0.6 \mathrm{M} \mathrm{NaCl}$; Fe15Cr alloy in $0.5 \mathrm{M} \mathrm{H}_{2} \mathrm{SO}_{4}$; and $\mathrm{Fe} 10 \mathrm{Cr}$ and $\mathrm{Fe} 20 \mathrm{Cr}$ alloys in $1 \mathrm{M} \mathrm{NaOH}$ [63-66]. In contrast, the passive layer of carbon steel B450C (Figure 12) tends to disappear after $360 \mathrm{~h}$, which coincides with the decrease in the $\mathrm{pH}$ value of the cement extract solution (Figure 7), when the steel lost the passive state. However, when the surface was still passivated (up to $168 \mathrm{~h}$ ), the greatest thickness was approximately $1.1 \mathrm{~nm}$, similar to that estimated from complex capacitance plots $(1.3-2.5 \mathrm{~nm})$ for $\mathrm{C} 15$ mild steel in $0.1 \mathrm{M} \mathrm{NaOH}$ alkaline solution [26].

\section{Conclusions}

The corrosion activities of commercial low chromium SS 430 ferritic and carbon steel grade B450C were studied during their exposure to cement extract model solution for $720 \mathrm{~h}$ (30 days). Before the immersion, SEM-EDS analysis suggested the presence of $\mathrm{Cr}$ $(\mathrm{C}-\mathrm{N})$ and $\mathrm{V}(\mathrm{C}, \mathrm{N})$ phases as well as $\mathrm{SiC}$ on the SS 430 surface and a low content of Mn, while on the B450C surface the phases of SiC, MnS, and Mn3C were probably present. XPS analysis revealed that after the exposure, Fe-oxyhydroxide and Cr-hydroxide were formed as corrosion products, as well as $\mathrm{CaCO}_{3}$.

The initial cement extract solution value of $\mathrm{pH}=13$ decreased abruptly to $\mathrm{pH} \sim 9$ after $168 \mathrm{~h}$ (7 days) of immersion of each steel, affected by $\mathrm{CO}_{2}$ dissolution from air (in $50 \mathrm{~mL}$ model solution), maintaining close to this value until the end of the experiment $(720 \mathrm{~h})$. Consequently, the open circuit values (OCP) of the carbon steel shifted to very negative (loss of the passive state), while the SS $430 \mathrm{OCP}$ values were positive (no passive state changes).

The Nyquist plots of EIS showed that, at the initial time of exposure, each steel presented capacitive behavior, attributed to charge transfer and mass transport. After the first $24 \mathrm{~h}$, the behavior changed to semi-linear diffusion impedance, associated with diffusion control of the corrosion process, because of the formed passive films on steel surfaces. However, the SS 430 maintained this behavior steadily until the end of the 
experiment (30 days), while the carbon steel B450C returned to capacitive behavior after $168 \mathrm{~h}$, when the passive state was lost because of $\mathrm{pH}$ change of the solution. The phase angle Bode diagrams confirmed these changes, keeping the SS 430 angle of $\approx-80^{\circ}$ until the end, while the carbon steel showed a tendency to very low angles, reaching $-1^{\circ}$, generally characteristic of capacitive surfaces

Two equivalent circuits (ECs) were proposed to investigate further the EIS data and describe the electrochemical activity of the studied steels.

The calculated values of $R_{p}$ for SS 430 increased over time as an indication of a highly protective passive layer, while for carbon steel $R_{p}$ reached its maximum value after $168 \mathrm{~h}$ and then decreased, maintaining minimum values approximately five orders lower than those of the stainless steel.

The calculated thickness $(d)$ of the passive layers revealed that they depend on the exposure time in cement extract solution and the nature of the steel. For SS 430, the thickness of the passive layer stabilized at about $2 \mathrm{~nm}$ and remained constant until the end of the test (30 days). In contrast, the passive layer on carbon steel B450C disappeared after $360 \mathrm{~h}(d \approx 0.1 \mathrm{~nm})$ because of lost state of passivity.

Author Contributions: Á.B. performed the preparation of samples and the corrosion tests. Á.B. and L.V. discussed the results and wrote the manuscript. S.F.J. contributed for EIS data analysis. M.C. and S.L. supervised the project. All correspondence should be addressed to L.V. All authors have read and agreed to the published version of the manuscript.

Funding: This research received no external funding.

Data Availability Statement: Data present in this study are available on request from the corresponding author. The data are not publicly to privacy issues.

Acknowledgments: Ángel Adrián Bacelis Jiménez acknowledges the Mexican National Council for Science and Technology (CONACYT) for scholarship granted to him for his Ph.D. study and for research stay at Department of Engineering and Applied Sciences of Bergamo University of Italy. The authors gratefully thank to the National Laboratory of Nano- and Biomaterials (LANNBIOCINVESTAV) for allowing the use of SEM-EDS and XPS facilities, also to Victor Rejón Moo and Wilian Cauich for their support in data acquisition.

Conflicts of Interest: The authors declare no conflict of interest.

\section{References}

1. Shi, X.; Xie, N.; Fortune, K.; Gong, J. Durability of steel reinforced concrete in chloride environments: An overview. Constr. Build. Mater. 2012, 30, 125-138. [CrossRef]

2. Aguirre, A.M.; Mejía de Gutiérrez, R. Durability of reinforced concrete exposed to aggressive conditions. Mater. Construcc. 2013, 63, 7-38. [CrossRef]

3. Lollini, F.; Carsana, M.; Gastaldi, M.; Redaelli, E. Corrosion behaviour of stainless steel reinforcement in concrete. Corros. Rev. 2019, 37, 3-19. [CrossRef]

4. Nóvoa, X.R. Electrochemical aspects of the steel-concrete system. A review. J. Solid State Electrochem. 2016, 20, 2113-2125. Available online: https:/ /link.springer.com/article/10.1007/s10008-016-3238-z (accessed on 21 February 2021). [CrossRef]

5. Liu, G.; Zhang, Y.; Wu, M.; Huang, R. Study of depassivation of carbon steel in simulated concrete pore solution using different equivalent circuits. Constr. Build. Mater. 2017, 157, 357-362. [CrossRef]

6. Wang, Z.; Di-Franco, F.; Seyeux, A.; Zanna, S.; Maurice, V.; Marcus, P. Passivation-induced physicochemical alterations of the native surface oxide film on 316L austenitic stainless steel. J. Electrochem. Soc. 2019, 166, C3376-C3388. [CrossRef]

7. Wang, L.; Seyeux, A.; Marcus, P. Ion transport mechanisms in the oxide film formed on 316L stainless steel surfaces studied by ToF-SIMS with ${ }^{18} \mathrm{O}_{2}$ isotopic tracer. J. Electrochem. Soc. 2020, 167, 101511. [CrossRef]

8. Sedriks, A.J. Corrosion of stainless steels. In Encyclopedia of Materials: Science and Technology, 2nd ed.; Jürgen, B., Flemings, M., Kramer, E., Veyssière, P., Cahn, R., Ilschner, B., Mahajna, S., Eds.; Elsevier: Amsterdam, The Netherlands, 2001; pp. 1707-1708. [CrossRef]

9. Ma, L.; Wiame, F.; Maurice, V.; Marcus, P. New insight on early oxidation stages of austenitic stainless steel from in situ XPS analysis on single-crystalline Fe-18Cr-13Ni. Corros. Sci. 2018, 140, 205-216. [CrossRef]

10. Gardin, E.; Zanna, S.; Seyeux, A.; Allion-Maurer, A.; Marcus, P. XPS and ToF-SIMS characterization of the surface oxides on lean duplex stainless steel-Global and local approaches. Corros. Sci. 2019, 155, 121-133. [CrossRef] 
11. Gardin, E.; Zanna, S.; Seyeux, A.; Allion-Maurer, A.; Marcus, P. Comparative study of the surface oxide films on lean duplex and corresponding single phase stainless steels by XPS and ToF-SIMS. Corros. Sci. 2018, 143, 403-413. [CrossRef]

12. Maurice, V.; Peng, H.; Klein, L.H.; Seyeux, A.; Zanna, S.; Marcus, P. Effects of molybdenum on the composition and nanoscale morphology of passivated austenitic stainless steel surfaces. Faraday Discuss. 2015, 180, 151-170. [CrossRef] [PubMed]

13. Papavinasam, S. Chapter 6-Modeling-internal corrosion. In Corrosion Control in the Oil and Gas Industry, 1st ed.; Papavinasam, S., Ed.; Gulf Professional Publishing: Houston, TX, USA, 2014; pp. 301-360. [CrossRef]

14. Olsson, C.O.A. Wet corrosion of stainless steels and other chromium-bearing alloys. In Encyclopedia of Interfacial Chemistry; Wandelt, K., Ed.; Elsevier: Amsterdam, The Netherlands, 2018; pp. 535-542. [CrossRef]

15. Lippold, J.C.; Kotecki, D.J. Welding Metallurgy and Weldability of Stainless Steels, 1st ed.; John Wiley \& Sons, Inc.: Hoboken, NJ, USA, 2005; pp. 19-55.

16. Bertolini, L.; Elsener, B.; Pedeferri, P.; Redaelli, E.; Polder, R. Corrosion of Steel in Concrete: Prevention, Diagnosis, Repair, 2nd ed.; Wiley-VCH Verlag GmbH \& Co. KGaA: Weinheim, Germany, 2013; pp. 263-283.

17. Pourbaix, M. Atlas of Electrochemical Equilibria in Aqueous Solutions, 2nd ed.; NACE: Houston, TX, USA, $1974 ;$ pp. $307-321$.

18. Taylor, H.F.W. Cement Chemistry, 2nd ed.; Thomas Telford: London, UK, 1997; pp. 351-384.

19. Li, K. Durability Design of Concrete Structures: Phenomena, Modeling, and Practice, 1st ed.; John Wiley \& Sons Singapore Pte. Ltd.: Solaris South Tower, Singapore, 2016; pp. 1-255.

20. Vago, E.R.; Calvo, E.J.; Stratmann, M. Electrocatalysis of oxygen reduction at well-defined iron oxide electrodes. Electrochemin. Acta 1994, 39, 1655-1659. [CrossRef]

21. Hem, J.D.; Cropper, W.H. Chemistry of Iron in Natural Water. Geological Survey Water-Supply Paper 1459-A; United States Department of the Interior Stewart L. Udall, Secretary: Washington, DC, USA, 1962; pp. 1-31.

22. Benitez, A.; Manzelli, A.; Macci, C.; Charreau, G.; Fernandez, L.; Husni, R.; Guitelman, N. Actions and mechanisms of deterioration of structures. In Concrete Structures: Rehabilitation and Maintenance; Paulo Helene \& Fernanda Pereira: São Paulo, Brazil, 2007; pp. 1-89.

23. Wang, L.; Zhan, S.; Tang, X.; Xiu, Q.; Qian, K. Pore solution chemistry of calcium sulfoaluminate cement and its effects on steel passivation. Appl. Sci. 2019, 9, 1092. [CrossRef]

24. Duffó, G.S.; Farina, S.B. Electrochemical behaviour of steel in mortar and in simulated pore solutions: Analogies and differences. Cem. Concr. Res. 2016, 88, 211-216. [CrossRef]

25. Poursaee, A.; Hansson, C.M. Potential pitfalls in assessing chloride-induced corrosion of steel in concrete. Cem. Concr. Res. 2009, 39, 391-400. [CrossRef]

26. Chakri, S.; Frateur, I.; Orazem, M.E.; Sutter, E.M.M.; Tran, T.T.M.; Tribollet, B.; Vivier, V. Improved EIS analysis of the electrochemical behaviour of carbon steel in alkaline solution. Electrochim. Acta 2017, 246, 924-930. [CrossRef]

27. Ghods, P.; Isgor, O.B.; McRae, G.A.; Gu, G.P. Electrochemical investigation of chloride-induced depassivation of black steel rebar under simulated service conditions. Corros. Sci. 2010, 52, 1649-1659. [CrossRef]

28. Gunay, H.B.; Isgor, O.B.; Ghods, P. Kinetics of passivation and chloride-induced depassivation of iron in simulated concrete pore solutions using electrochemical quartz crystal nanobalance. Corrosion 2015, 71, 615-627. [CrossRef]

29. Hussain, R.R.; Alhozaimy, A.; Al-Negheimish, A.; Singh, D.D.N. Time-dependent variation of the electrochemical impedance for thermo-mechanically treated versus plain low alloy steel rebars in contact with simulated concrete pore solution. Constr. Build. Mater. 2014, 73, 283-288. [CrossRef]

30. Li, L.; Sagüés, A.A. Chloride corrosion threshold of reinforcing steel in alkaline solutions-Open-circuit immersion tests. Corrosion 2001, 57, 19-28. [CrossRef]

31. Poursaee, A. Corrosion of steel bars in saturated $\mathrm{Ca}(\mathrm{OH})_{2}$ and concrete pore solution. Concr. Res. Lett. $2010,1,90-97$.

32. Williamson, J.; Isgor, O.B. The effect of simulated concrete pore solution composition and chlorides on the electronic properties of passive films on carbon steel rebar. Corros. Sci. 2016, 106, 82-95. [CrossRef]

33. Veleva, L.; Alpuche-Aviles, M.A.; Graves-Brook, M.K.; Wipf, D.O. Comparative cyclic voltammetry and surface analysis of passive films grown on stainless steel 316 in concrete pore model solutions. J. Electroanal. Chem. 2002, 537, 85-93. [CrossRef]

34. Veleva, L.; Alpuche-Aviles, M.A.; Graves-Brook, M.K.; Wipf, D.O. Voltammetry and surface analysis of AISI 316 stainless steel in chloride-containing simulated concrete pore environment. J. Electroanal. Chem. 2005, 578, 45-53. [CrossRef]

35. Montemor, M.F.; Simoes, A.M.; Ferreira, M.G. Analytical characterization of the passive film formed on steel in solutions simulating the concrete interstitial electrolyte. Corrosion 1998, 54, 347-353. [CrossRef]

36. Montemor, M.F.; Simoes, A.M. Analytical characterization of the passive film formed on steel in cement past intersticial solutions. Port. Electrochim. Acta 1995, 13, 453-456.

37. Bacelis, A.; Veleva, L.; Alpuche-Avilés, M.A. Copper corrosion behavior in simulated concrete-pore solutions. Metals 2020, 10, 474. [CrossRef]

38. Ming, J.; Wu, M.; Shi, J. Corrosion resistance of a Cr-bearing low-alloy reinforcing steel: Effect of surface condition, alkaline solution, and chloride content. J. Mater. Civ. Eng. 2020, 32, 04020034. [CrossRef]

39. Outokumpu Stainless, A.B. Handbook of Stainless Steel; Avesta Resarch Centre: Avesta, Sweden, 2013; pp. 8-81.

40. ASTM G31-12a. Standard Guide for Laboratory Immersion Corrosion Testing of Metals; ASTM International: West Conshohocken, PA, USA, 2012. 
41. ASTM, G-1-03. Standard Practice for Preparing, Cleaning, and Evaluating Corrosion Test Specimens; ASTM International: West Conshohocken, PA, USA, 2017.

42. Yamashita, T.; Hayes, P. Analysis of XPS spectra of $\mathrm{Fe}^{2+}$ and $\mathrm{Fe}^{3+}$ ions in oxide materials. Appl. Surf. Sci. 2008, 254, 2441-2449. [CrossRef]

43. Jia, T.; Ni, R.; Wang, H.; Shen, J.; Wang, Z. Investigation on the formation of Cr-rich precipitates at the interphase boundary in type 430 stainless steel based on austenite-ferrite transformation kinetics. Metals 2019, 9, 1045. [CrossRef]

44. Heo, S.Y.; Shin, J.H.; Kim, D.-I.; Oh, J.Y.; Zhang, S.H.; Kim, K.H. Microstructure and mechanical properties of Cr-V-C-N films. Surf. Eng. 2015, 31, 513-518. [CrossRef]

45. Apostolopoulos, C.; Drakakaki, A.; Apostolopoulos, A.; Koulouris, K. Comparison of the mechanical response of B400c and B450c dual phase steel bar categories, in long terms. Frat. Integrità Strutt. 2019, 50, 548-559. [CrossRef]

46. Apostolopoulos, C.; Drakakaki, A.; Apostolopoulos, A.; Matikas, T.; Rudskoi, A.I.; Kodzhaspirov, G. Characteristic defectscorrosion damage and mechanical behavior of dual phase rebar. Mater. Phys. Mech. 2017, 30, 1-19.

47. Moulder, J.F.; Stickle, W.F.; Sobol, P.E.; Bomben, K.D. Handbook of X-ray Photoelectron Spectroscopy: A Reference Book of Standard Spectra for Identification and Interpretation of XPS Data; Physical Electronics: Chanhassen, MN, USA, 1995.

48. Luo, H.; Su, H.; Dong, C.; Xiao, K.; Li, X. Electrochemical and passivation behavior investigation of ferritic stainless steel in alkaline environment. Constr. Build. Mater. 2015, 96, 502-507. [CrossRef]

49. Song, Y.Y.; Bhadeshia, H.K.D.H.; Suh, D.-W. Stability of stainless-steel nanoparticle and water mixtures. Powder Technol. 2015, 272, 34-44. [CrossRef]

50. Sekkal, W.; Zaoui, A. Nanoscale analysis of the morphology and surface stability of calcium carbonate polymorphs. Sci. Rep. 2013, 3, 1587. [CrossRef] [PubMed]

51. Umoru, L.E.; Afonja, A.A.; Ademodi, B. Corrosion study of AISI 304, AISI 321 and AISI 430 stainless steels in a tar sand digester. J. Miner. Mater. Charact. Eng. 2008, 7, 291-299. [CrossRef]

52. Avci, R.; Davis, B.H.; Wolfenden, M.L.; Beech, I.B.; Lucas, K.; Paul, D. Mechanism of MnS-mediated pit initiation and propagation in carbon steel in an anaerobic sulfidogenic media. Corros. Sci. 2013, 76, 267-274. [CrossRef]

53. Shoesmith, D.W.; Taylor, P.; Bailey, M.G.; Ikeda, B. Electrochemical behaviour of iron in alkaline sulphide solutions. Electrochim. Acta. 1978, 23, 903-916. [CrossRef]

54. Sarango de Souza, J.; De Oliveira, L.A.; Sayeg, I.J.; Antunes, R.A. Electrochemical study of the AISI 409 ferritic stainless steel: Passive film stability and pitting nucleation and growth. Mater. Res. 2017, 20, 1669-1680. [CrossRef]

55. Zhang, X.; Fan, L.; Xu, Y.; Li, J.; Xiao, X.; Jiang, L. Effect of aluminum on microstructure, mechanical properties and pitting corrosion resistance of ultra-pure 429 ferritic stainless steels. Mater. Des. 2015, 65, 682-689. [CrossRef]

56. Freire, L.; Carmezim, M.J.; Ferreira, M.G.S.; Montemor, M.F. The electrochemical behaviour of stainless steel AISI 304 in alkaline solutions with different $\mathrm{pH}$ in the presence of chlorides. Electrochim. Acta. 2011, 56, 5280-5289. [CrossRef]

57. Luo, H.; Su, H.; Dong, C.; Li, X. Passivation and electrochemical behavior of 316L stainless steel in chlorinated simulated concrete pore solution. Appl. Surf. Sci. 2017, 400, 38-48. [CrossRef]

58. Shi, J.; Ming, J.; Sun, W. Electrochemical performance of reinforcing steel in alkali-activated slag extract in the presence of chlorides. Corros. Sci. 2018, 133, 288-299. [CrossRef]

59. Shi, J.; Sun, W.; Jiang, J.; Zhang, Y. Influence of chloride concentration and pre-passivation on the pitting corrosion resistance of low-alloy reinforcing steel in simulated concrete pore solution. Constr. Build. Mater. 2016, 111, 805-813. [CrossRef]

60. Pujar, M.G.; Parvathavarthini, N.; Dayal, R.K. Some aspects of corrosion and film formation of austenitic stainless steel type 316LN using electrochemical impedance spectroscopy (EIS). J. Mater. Sci. 2007, 42, 4535-4544. [CrossRef]

61. Orazem, M.; Frateur, I.; Tribollet, B.; Vivier, V.; Marcelin, S.; Pebere, N.; Bunge, A.L.; White, E.A.; Riemer, D.P.; Musiani, M. Dielectric properties of materials showing constant-phase-element (CPE) impedance response. J. Electrochem. Soc. 2013, 160, C215-C225. [CrossRef]

62. Carmezim, M.J.; Simões, A.M.; Montemor, M.F.; Da Cunha Belo, M. Capacitance behaviour of passive films on ferritic and austenitic stainless steel. Corros. Sci. 2005, 47, 581-591. [CrossRef]

63. BenSalah, M.; Sabot, R.; Triki, E.; Dhouibi, L.; Refait, P.; Jeannin, M. Passivity of Sanicro28 (UNS N-08028) stainless steel in polluted phosphoric acid at different temperatures studied by electrochemical impedance spectroscopy and Mott-Schottky analysis. Corros. Sci. 2014, 86, 61-70. [CrossRef]

64. Niu, W.; Lillard, R.S.; Li, Z.; Ernst, F. Properties of the passive film formed on interstitially hardened AISI 316L stainless steel. Electrochim. Acta 2015, 176, 410-419. [CrossRef]

65. Heuer, A.H.; Kahn, H.; Ernst, F.; Michal, G.M.; Hovis, D.B.; Rayne, R.J.; Martin, F.J.; Natishan, P.M. Enhanced corrosion resistance of interstitially hardened stainless steel: Implications of a critical passive layer thickness for breakdown. Acta Mater. 2012, 60, 716-725. [CrossRef]

66. Olsson, C.O.A.; Landolt, D. Passive films on stainless steels-Chemistry, structure and growth. Electrochim. Acta 2003, 48, 1093-1104. [CrossRef] 